\title{
Revisiting native and immigrant entrepreneurial activity
}

\author{
Andrea Lassmann · Christian Busch
}

Accepted: 30 May 2015/Published online: 21 June 2015

(C) Springer Science+Business Media New York 2015

\begin{abstract}
Entrepreneurial activity differs substantially across immigrant groups in the USA, but relating self-employment rates in the US to home-country selfemployment shares has provided inconclusive results in previous studies. This paper offers new evidence on the relationship between native self-employment and the self-employment decision of immigrants and their descendants. We argue that the previous literature has neglected to account for different proxies of entrepreneurial behavior and for determinants of self-employment in the country of origin. We find mixed evidence of a significant relationship between entrepreneurial activity of US immigrants and two different measures of entrepreneurial activity in their respective countries of origin. Our findings suggest that differences in selfemployment across immigrants of different origin are to some degree an expression of the behavior acquired under varying economic and institutional environments.
\end{abstract}

Keywords Self-employment · Entrepreneurship · Immigration · Development · Culture

A. Lassmann $(\square)$

KOF Swiss Economic Institute, ETH Zurich, G118, Leonhardstrasse 21, 8092 Zurich, Switzerland e-mail: lassmann@kof.ethz.ch

Present Address:

C. Busch

State Secretariat of Economic Affairs SECO,

Effingerstrasse 1, 3003 Bern, Switzerland
JEL Classifications $\quad$ A13 $\cdot$ J24 $\cdot$ J61 $\cdot$ L26 $\cdot$

$\mathrm{O} 11 \cdot \mathrm{Z} 10$

\section{Introduction}

The variation in entrepreneurial activity across countries is substantial. Rates of self-employment-a common proxy for entrepreneurship—range from a share in total employment of $6.8 \%$ in Slovakia to $68.6 \%$ in Cameroon. Entry rates of new businesses vary between a mere $2.4 \%$ in Haiti and $19 \%$ in New Zealand. ${ }^{1}$ What explains these large differences? Most of the literature has focused on individual characteristics of entrepreneurs and has identified strong determinants such as age, gender, education, and economic endowments (e.g., Djankov et al. 2005, 2006). As improved cross-country data became available more recently, there has been an increased effort to reveal more fundamental explanations of entrepreneurial activity, including institutions, geography, and culture (e.g., Guiso et al. 2006; Klapper et al. 2006; Glaeser 2007; Ardagna and Lusardi 2010; Liñán and Fernandez-Serrano 2014). Geographical and institutional aspects such as corruption, law enforcement, or the protection of property rights can be measured to

\footnotetext{
1 Sources: International Labour Office database (average figures, 1969-2000) of the ILO Bureau of Statistics and the World Bank Group Entrepreneurship Survey and Database (2008).
} 
some degree and may shape entrepreneurial patterns and culture. The analysis of the separate influences of culture and institutions is complicated by the fact that both are correlated and proxies of entrepreneurial activity may be endogenous to the level of development or to other (even unmeasurable) characteristics across countries. One way to circumvent this problem is to study the behavior of migrants. The basic idea of such an epidemiological approach (Fernández 2008) is the assumption that immigrants in the same country share by definition the same economic and institutional environment. Yet, the individual environment of immigrants has changed while aspects of their past environment can be held constant.

In this paper, we shed light on the relationship between immigrant entrepreneurial activity and native entrepreneurial patterns. Conditional on home-country self-employment rates, we estimate country-specific differences in entrepreneurial activity by observing the probability of immigrants with different nationality in the USA to become self-employed. Accordingly, native patterns serve as the relevant cultural concept to this paper (see also Liñán and Fernandez-Serrano 2014). As opposed to a large fraction of previous work, we propose to focus on two different measures of entrepreneurship that are supposed to capture different types of economic activity. By measuring differences in observed outcomes within the same market, we hold constant a number of alternative explanatory variables such as the institutional and economic environment. In order to analyze the role for a potential effect of native self-employment, we test whether this country-specific component of entrepreneurial activity can be related to similar measures in the immigrants' countries of origin (COO). Because the native patterns may depend on home-country economic and institutional characteristics, we condition on factors that are correlated with occupation choices.

Our results suggest a positive relationship between the propensity to become incorporated self-employed in the USA and employer shares in the home country which is captured by other factors that may shape entrepreneurial patterns once we account for them. However, the effect is significantly increasing in home-country GDP per capita, pointing to the importance of levels of development and initial endowments as determinants of the individual self-employment choice. We find a significant but negative relationship between overall self-employment in the USA and selfemployment shares in the home country. These two results are interesting in various regards. First, they provide evidence for the hypothesis that entrepreneurial concepts vary between countries that differ in income. Second, they may indicate that varying economic and institutional environments may have shaped entrepreneurial patterns in the respective country of origin (e.g., Stuetzer et al. 2014; Wyrwich 2015), leading to a transfer of relevant values and skills to the country of immigration and affecting entrepreneurial choices. They point to the necessity to distinguish between different types of entrepreneurs. We further conclude that other factors that determine occupation choices - in particular GDP_-should be accounted for when analyzing the relationship between the propensity to become an entrepreneur and aggregate home-country self-employment rates.

To provide a more thorough investigation of a potential cultural explanation of such home-country effects, we study the behavior of second-generation immigrants. This has become a common approach to test the effect of cultural values (Fernández and Fogli 2006, 2009; Giuliano 2007; Fernández 2008; Alesina and Giuliano 2010, 2011). We thus consider a sample of American natives with foreign ancestry to test the robustness of our results. This alternative approach assumes that cultural beliefs and attitudes as well as acquired behavior are imported into the country of immigration and show some degree of persistence even if the institutional environment changes, i.e., that they are intergenerationally transmitted. We are not able to confirm that cultural influences-proxied by past home-country self-employment rates-are persistent determinants of the self-employment decision. However, the results are quantitatively robust to the sample of recent immigrants to the USA. Since entrepreneurship stimulates economic growth (e.g., Audretsch et al. 2006; Autio 2007; Acs et al. 2012), our findings may provide a tentative argument for foreign aid aimed at the creation of institutions that foster entrepreneurship.

The remaining part of this paper is organized as follows. The next section develops a motivation for the use of different proxies for entrepreneurial activity. It sheds first light on the need to control for omitted variables related to immigrants' countries of origin. Section 3 gives a short overview of the literature on entrepreneurial culture and on institutional and 
cultural determinants of entrepreneurial activity. Section 4 describes the data and empirical strategy used, followed by a presentation of the empirical results including robustness checks in Sect. 5. The final section concludes.

\section{Differences in entrepreneurship}

Differences in self-employment rates across immigrant groups in the USA are persistent and significant (e.g., Borjas 1986; Yuengert 1995; Fairlie and Meyer 1996; Lofstrom 2002; Fairlie et al. 2010). Previous studies were able to account for most of the determinants of entrepreneurial activity at the individual level, and the remaining differences have often been attributed to ethnic or cultural differences between immigrants from different nations. If such cultural explanations are valid, we should be able to observe similar differences in entrepreneurial activity across immigrant home countries. However, empirical research has failed to show conclusive evidence in favor of such systematic differences. While Yuengert (1995) finds a positive correlation with home-country self-employment rates, more recent literature shows that aggregate self-employment shares of immigrants are uncorrelated with average selfemployment shares in the country of origin (Fairlie and Meyer 1996; Tubergen 2005), or even negatively correlated (Akee et al. 2013).

We account for the inconclusive evidence about the relationship between home-country and immigrationcountry self-employment by extending the existing research in several aspects. We argue that the difference is crucially due to differences in the definition of entrepreneurial activity (see also Acs et al. 2008; Levie et al. 2014). So far, the literature has primarily focused on overall self-employment rates as a proxy or has at best used non-agricultural self-employment (Fairlie and Meyer 1996). This measure includes ownaccount workers and has undesirable properties since in many countries, high self-employment rates are simply a result of a large subsistence economy. The use of overall self-employment may also be flawed in the country of immigration. While certainly many of the individuals who report to be self-employed correspond to the notion of entrepreneurs, others may not be able to choose their employment status. For instance, unemployment and a lack of language skills or recognition of foreign qualifications may push immigrants who would otherwise prefer employed work into self-employment. This concern may be particulary valid in certain sectors, such as the service, the transport, and the retail sectors. The use of selfemployment shares thus understates the role of such push-factors. Cross-country analysis is then complicated by the fact that people working in certain professions may be self-employed in some countries, while in others, the same jobs are mainly carried out by employees. Finally, if we have in mind a notion of entrepreneurs as building firms, growing through capital accumulation and investment, and creating employment and innovation, which seems to be the case in much of the literature (see, e.g., Bjørnskov and Foss 2008; Liñán and Fernandez-Serrano 2014; Henrekson and Sanandaji 2014), we certainly have to exclude most of these micro-entrepreneurs. For these reasons, we focus on a more narrow definition of entrepreneurs in the USA by accounting for differences among individuals who report to be incorporated self-employed rather than for differences among the overall self-employed. ${ }^{2}$ While the former refers to employers and other self-employed individuals that own an incorporated business or farm, the latter refers to individuals whose businesses and farms are not incorporated. By using incorporated self-employment, our analysis should be able to mitigate the influence of push-factors that are likely to be driven by endowment and regulatory factors and thus should facilitate the comparison with entrepreneurial activity in the countries of origin. Similarly, we suggest to relate this measure to the share of employers in the country of origin as an alternative proxy to overall self-employment. This concept does not entirely correspond to the variable using incorporated self-employed individuals that we generated for US immigrants. Nevertheless, we believe that such a comparison is an improvement over the existing literature. ${ }^{3}$

The correlation between US and home-country self-employment rates and between US incorporated self-employment rates and home-country employer

\footnotetext{
$\overline{2}$ This measure has also been used, for instance, by Borjas (1986), Evans and Leighton (1989), however, in a different context.

3 The variable is calculated from the ILO Laborsta database as the share of employers in total active population and relates to averages over the years 1969-2000. Note that the panel from which the average is calculated is unbalanced in the time dimension.
} 
shares is visualized in Fig. 1. The figure on the righthand side-indicating a positive correlation between the latter-suggests that the distinction between these two variables provides additional information on the relationship between entrepreneurial behavior in the country of origin and the country of immigration. Consider, for instance, the puzzle why Mexican selfemployment amounts to roughly one quarter, while the self-employment ratio of Mexican immigrants in the USA is only about $6 \%$ (Fairlie and Woodruff 2010). In the data at hand, self-employment shares amount to $25 \%$ in Mexico and to $7.1 \%$ in the USA. At the same time, the employer share amounts to $2.4 \%$ in Mexico and to $1.6 \%$ in the USA. This simple comparison may tell us that the notion of self-employment may differ across countries (see also Acs and Virgill 2010, for an overview on entrepreneurship in developing countries) and supports the choice of an alternative proxy for entrepreneurial activity.

What are the reasons underlying these patterns? While previous research has chiefly explained immigrant differences by resorting to observable characteristics of immigrants, we argue that part of the puzzle can be explained by adding information about the country of origin. Further determinants related to the country of origin may affect the individual's choice of profession. For instance, income in the home country may matter for selfemployment in the country of immigration (Oyelere and Belton 2012). Our basic argument is simple.
Consider again the example of Mexico. If we want to address this puzzle, we should not only look at determinants of Mexican self-employment in the USA but also explain why average Mexican selfemployment is high. The reason is that even though high-quality census data are available, it is difficult to evaluate informal and job-specific characteristics of immigrants (Hendricks 2002). For instance, wealth is only incompletely measured in most of these data sets, but is an important determinant to account for the unequal distribution in initial conditions between immigrants from different countries. There are good reasons to believe that wealth depends on the differences in levels of income across countries of origin. Similarly, immigrants' institutional knowledge differs, which could explain why immigrants from some given country may be more familiar with the institutional environment in the country of immigration.

We thus attempt to bridge the micro-level literature with the literature that explains entrepreneurial activity across countries by performing a multilevel analysis of the determinants of self-employment (see, e.g., Stuetzer et al. 2014). Figure 2 provides clear support for the importance of taking into account determinants of selfemployment in the home country. The upper panel of Fig. 2 compares home-country self-employment rates to levels of GDP per capita. It shows that selfemployment rates are negatively correlated with income (panel on the left-hand side), while employer

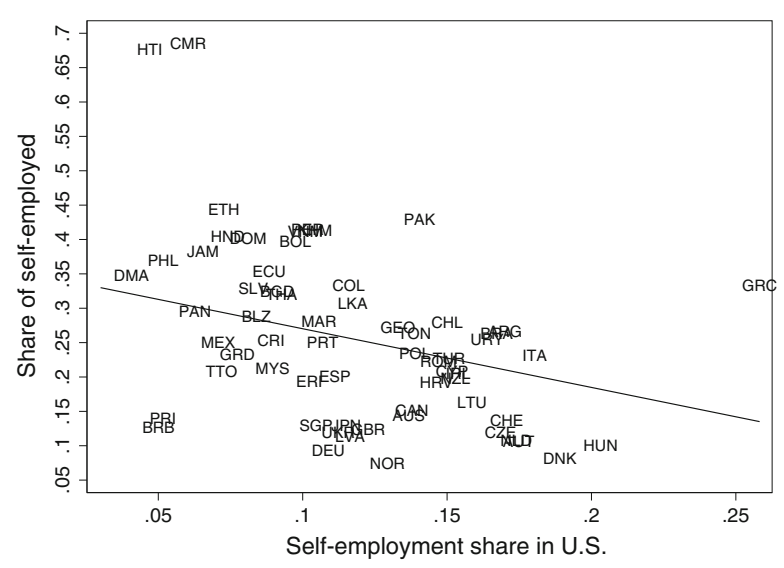

Fig. 1 Correlation of immigrant and home-country selfemployment share. Notes: Self-employment and employer share in total active population (ILO Laborsta, average 1969-2000) on $\mathrm{y}$-axis. US number of self-employed and incorporated self-

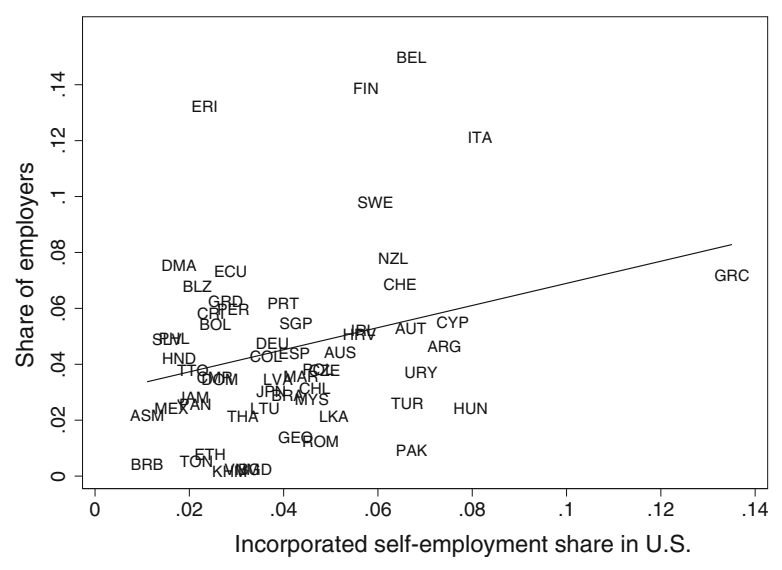

employed in total observations by country, excluding unemployed individuals and individuals not at work in USA (Ruggles et al. 2008) on $\mathrm{x}$-axis 

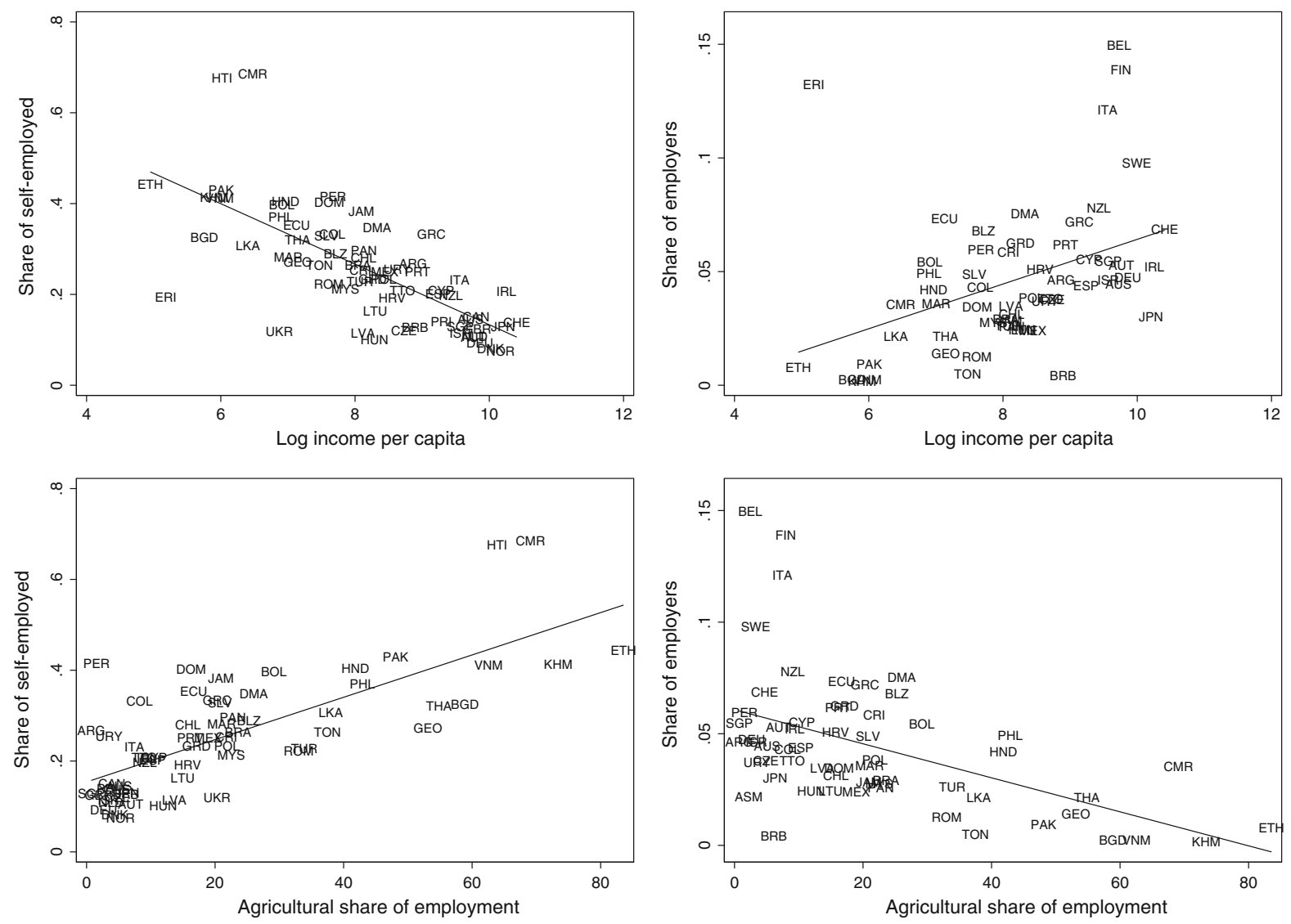

Fig. 2 Correlation of self-employment with employer share and log GDP per capita/agricultural employment across countries. Notes: Self-employment and employer share in total active population: ILO Laborsta, average 1969-2000. Constant 2000

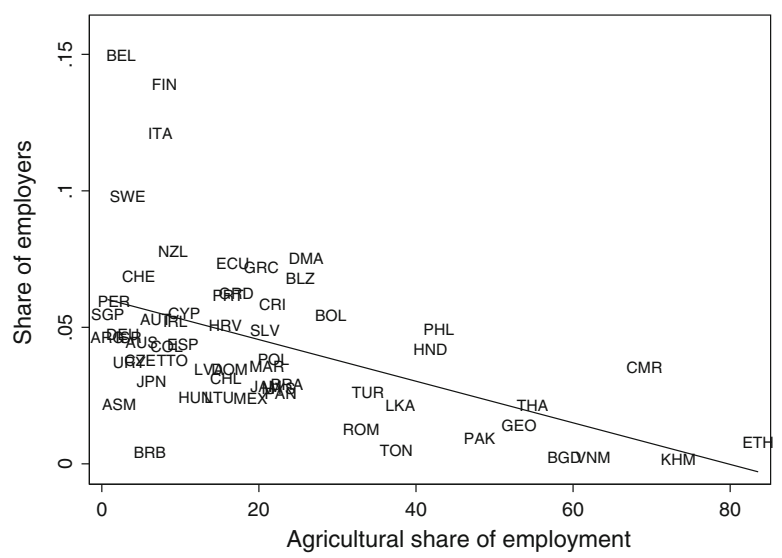

GDP p.c. in USD and agricultural employment in total employment: World Development Indicators, average 1960-2000

shares are positively correlated with income (panel on the right-hand side). The figure suggests that the two proxies do indeed capture two different aspects of entrepreneurship. While overall self-employment rates seem to capture the prevalence of subsistence and ownaccount workers and are likely to be an outcome of underdevelopment, employer shares seem much more reasonable as a proxy for a Schumpeterian type of entrepreneurial activity. The lower panel shows the correlation between agricultural employment and selfemployment. The strong correlations confirm that selfemployment is rather prevalent in underdeveloped countries with high agricultural employment, while agricultural employment and employer shares are negatively correlated. Referring to the Mexican example above, these figures provide one valuable explanation for the missing link. While observed differences in home-country self-employment and self-employment

in the country of origin are puzzling from the individual perspective of some countries, they may well be explained by resort to differences across countries of origin. Accordingly, we suggest that controlling for income and other variables adds important information.

The previous figures indicate that we have to be careful when attributing native patterns to cultural values because those are confounded by other factors. Furthermore, recent migrants are subject to shocks (language, knowledge about legal issues, uncertainty, etc.) which could induce a deviation from their normal behavior (Fernández 2008). It is quite likely that immigrants have beliefs and preferences that are not representative of the average in their home country even if much of the self-selection can be accounted for by observable differences in education, occupation, and other direct individual characteristics. This may 
tend to bias the estimations toward not finding any significant correlation with home-country self-employment. Alternatively, if returns to entrepreneurship are relatively higher than in the home country, this may bias the results toward finding a significant correlation. The bias emerging from such shocks and from non-random selection could be severe in the short run. To address these issues, we study the selfemployment behavior of individuals with foreign ancestry to test whether native experience related to entrepreneurial institutions is transmitted to future generations. This approach is described in the next section.

\section{Related literature}

In analyzing the determinants of entrepreneurship at the aggregate level, we can distinguish between determinants at the level of the individual and determinants at the macro-level. Due to the relatively early availability of census data in several countries, entrepreneurship has been extensively studied at the micro-level. More recently, data specifically aimed at the analysis of entrepreneurial behavior have become available, e.g., the Global Entrepreneurship Monitor (GEM) and COMPENDIA databases. A large number of studies seek to explain differences in the choice of self-employment among individuals of different race and ethnic groups or from different countries conditional on socioeconomic variables for the USA, Germany, and the UK. The explanatory variables are largely driven by the availability of data and typically include age, gender, education, marital status, language proficiency, income, capital assets, and health limits (e.g., Evans and Jovanovic 1989; Evans and Leighton 1989; Blanchflower and Oswald 1998). In general, self-employment is more prevalent among the male, the older, the better educated, and the married population (e.g., Blanchflower 2000; Blanchflower et al. 2001). Furthermore, self-employment rates differ by race and ethnic group (e.g., Borjas 1986; Rees and Shah 1986; Fairlie and Meyer 1996; Clark and Drinkwater 2000), with immigrant self-employment typically exceeding native-born self-employment.

Various potential reasons for the significant differences in the probability to become self-employed among different groups or against native individuals are identified. First, using dummies for immigrant cohorts, Borjas (1985), Borjas (1986) show that strong assimilation effects of immigrant self-employment and earnings exist. After 10 years of residence in the USA, the probability to become self-employed is at least as large for immigrants as for natives. Second, a set of factors may push immigrants out of paid employment into self-employment. Factors like discrimination, lack of qualifications recognition, and poor language skills lower the relative returns to paid employment and therefore push immigrants into selfemployment. Moreover, restrictions related to the legal status of the immigrant (i.e., citizenship, visa) may influence self-employment in the country of immigration (see Constant and Zimmermann 2006; Oyelere and Belton 2008). Third, factors such as the existence of ethnic enclaves may pull immigrants into self-employment. Enclaves provide a self-sustaining environment creating a comparative advantage in catering group-specific needs. Large enclaves potentially provide less expensive co-ethnic labor supply. For these reasons, they may foster the likelihood of self-employment of immigrants (Aldrich and Waldinger 1990; Fairlie and Meyer 1996). ${ }^{4}$

Individual self-employment is not only determined by individual characteristics, skills, and abilities. It is highly dependent on demographic, economic, institutional, geographical, political, and technological conditions that potential entrepreneurs face (e.g., Reynolds et al. 1994, 1999; Djankov et al. 2002; Klapper et al. 2006; Glaeser 2007; Djankov 2009; Bjørnskov and Foss 2008; Ardagna and Lusardi 2010; Klapper et al. 2010; Bruhn 2011; Dreher and Gassebner 2013; FernándezSerrano and Romero 2014). For instance, high costs of start-up procedures and complicated procedures related to contract enforcement or property registration as well as other regulatory institutions may discourage individual self-employment decisions.

While the literature described above focuses on observable conditions, the self-employment decision will also depend on personal and cultural preferences and beliefs about work and profession. The idea that cultural influences matter for entrepreneurial activity

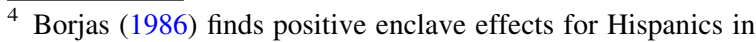
the USA, while Clark and Drinkwater (2000) show that ethnic enclaves decrease the probability to become self-employed in the UK. Further hypotheses are mentioned in the literature, including the sectoral choice model (Fairlie and Meyer 1996) or the tax avoidance hypothesis (Yuengert 1995).
} 
has been raised first by Max Weber's famous argument that Protestant ethics induced high savings, investment, and the accumulation of wealth. Further seminal work suggesting that culture matters for various economic outcomes includes Greif (1989, 1993, 1994), Putnam et al. (1993), and Landes (1999). There are several reasons why cultural explanations are difficult to test and to separate from institutional explanations. First, culture is much harder to measure than other determinants of economic activity, including institutions. Second, culture can be defined in many ways, and the channels through which culture may influence economic outcomes are manifold such that it is difficult to state refutable hypotheses (Guiso et al. 2006). Similarly, there are no clear hypotheses that give guidance as to which cultural traits should matter. Third, attempts to measure culture by resort to survey data suffer from severe cognitive biases (Halo effects). Finally, culture often shows a remarkable degree of persistence, but eventually is not immutable over time, and it may not have an independent role in determining economic outcomes. For instance, Greif $(1993,1994)$ demonstrates that institutions and culture are two closely related dimensions. This complicates the use of historical events as instrumental variables since cultural change is endogenous to the institutional environment.

Two approaches are particularly acclaimed as an attempt to address these issues as summarized in Fernández (2008). First, survey-based studies analyze the beliefs and preferences of people drawn from surveys such as the World Value Survey (e.g., Guiso et al. 2003, 2004), or the Schwartz Value Survey (e.g., Fernández-Serrano and Romero 2014). Since this approach faces potential endogeneity problems, it is necessary to exploit suitable identification strategies (e.g., by choosing appropriate instruments or quasi-experiments) or methods in order to establish a causal relationship between culture and economic outcomes (e.g., Liñán and Fernandez-Serrano 2014; Tabellini 2010; Guiso et al. 2006; Iyer and Schoar 2010; Alesina et al. 2011). Second, culture may be analyzed using epidemiological approaches that study the economic behavior of immigrants (e.g., Carroll et al. 1994; Hendricks 2002). However, immigrants may depart from their traditional behavior due to the exposure to the new environment and because immigrant groups are not necessarily a representative sample of their home country (Fernández 2008). As a consequence, epidemiological approaches run the risk of producing insignificant results for culture, and they do usually not allow us to draw causal inference about the relationship of interest. Analyzing the behavior of second-generation immigrants has become a common approach to mitigating problems of selection and omitted variables (see Fernández and Fogli 2009; Giuliano 2007; Alesina and Giuliano 2010, 2011), although this approach may attenuate the role of country of origin effects even further.

This paper builds on the previous literature that has employed an epidemiological approach in the context of self-employment decisions as described above. It is based on the hypothesis that cultural values are persistent (Roland 2004; Bisin and Verdier 2010) and the changing environment that migrants face may thus be exploited as a source of variation (Guiso et al. 2006). But while previous work has focused on reasons for differences in selfemployment among immigrant groups in the new environment, determinants of differences in selfemployment across immigrant groups may also be related to the country of origin. The idea underlying this approach is that immigrants arrive in the new environment with certain cultural and economic endowments (see Fernández 2008; Fernández and Fogli 2009). We hypothesize that self-employment in the country of origin may affect the selfemployment choice in the country of immigration. Local entrepreneurial observables as determinants of latent and nascent entrepreneurship have been analyzed in a variety of articles (e.g., Armington and Acs 2002; Bergmann and Sternberg 2007; Mueller 2006). For instance, Stuetzer et al. (2014) show that regional characteristics indirectly affect individual entrepreneurial intentions and activity by shaping individual perceptions about such activity. Likewise, Wyrwich (2015) finds that the individual environment shapes entrepreneurial values that are intergenerationally transmitted. In fact, it is likely that self-employment and employer shares in the country of origin capture variables through which such latent or nascent activity is transmitted.

In the remainder of this paper, we show that accounting for different proxies of entrepreneurial activity and for differences in the determinants of selfemployment across countries provides a more 
transparent picture of the relationship between native entrepreneurial patterns and self-employment. Finally, by analyzing the relationship between ancestor-country self-employment and the self-employment decision of second-generation immigrants, we test the robustness of a potential role for culture. It has to be noted that our results do neither allow a causal interpretation nor shed light on the transmission channels through which such factors may influence entrepreneurial behavior.

\section{Data and empirical strategy}

We study the self-employment decision of immigrants from different nations in the USA using the $5 \%$ sample of the 2000 US Census Ruggles et al. (2008). ${ }^{5}$ The data set at hand has a number of advantages. First, it covers a large number of observations, in particular with respect to more recent census data. This is particularly important as the number of self-employed workers with respect to the overall population is small. Having only a few confirming observations is a common problem in binary data regressions and possibly results in severe bias. The sample contains 14,081,466 observations, of which 1,584,082 observations are immigrants. We omit all individuals younger than 20 and older than 69 years. $^{6}$ Second, the data set covers a wide range of geographical, demographic, and socioeconomic

\footnotetext{
5 Such an approach has been used, among others, by Carroll et al. (1994), Hendricks (2002), and Osili and Paulson (2008). Hendricks (2002) estimates differences in human capital endowments by measuring differences in labor earnings across US immigrants with identical skills using 1990 US Census data; Carroll et al. (1994) study cultural differences in savings patterns using immigrant data for Canada and the USA; and Osili and Paulson (2008) examine the effect of home-country institutions on the financial behavior of immigrants in the USA. The same data set is used by Michelacci and Silva (2007) to analyze how local entrepreneurship contributes to business creation, see also Yuengert (1995), Fairlie and Meyer (1996), Fairlie and Woodruff (2010).

${ }^{6}$ For ease of calculation, it is restricted to include 100,000 randomly selected US native citizens in the regressions displayed in Table 7 in the Appendix of this paper. The remaining number of observations is $1,324,102$. This plays no role with respect to the estimates reported in Sect. 5 (no US natives included).
}

variables which have been found to explain the probability of being self-employed. These include age, gender, education, marital status, and number of children in the household. In addition, we obtained the US place of residence, country of origin, duration of stay in the USA in years, proficiency in English, income, and occupation from the same source. This allows us to control for the most systematic biases resulting from differences across immigrant groups or due to immigrant self-selection. ${ }^{7}$ Third, we can distinguish between incorporated and unincorporated self-employment. These terms refer to employers and other self-employed individuals who own an incorporated business or farm and those whose businesses and farms are not incorporated. Although both measures of entrepreneurial activity have limitations (e.g., they do not capture the size of the firm, the year the business was started, etc.), they may reasonably proxy the propensity to become an entrepreneur and are commonly used in the literature (see Blanchflower 2000; Glaeser 2007). Summary statistics are reported in Table 6 in the Appendix. The reduced sample includes 108 thousand self-employed and about 36 thousand incorporated self-employed observations, of which 99 thousand and 33 thousand are immigrants. With about 1.2 million immigrants in the sample, the self-employment share and incorporated self-employment share amount to 8.2 and $2.7 \%$, respectively. We drop the 55 thousand observations from the sample that report to be unemployed. ${ }^{8}$ The remaining sample size is $1,052,446$. The selfemployment share and the incorporated self-employment share in total observations amount to 9.9 and $3.3 \%$ overall and to 9.1 and $3.1 \%$ for immigrants.

The two dependent variables are binary and refer to total self-employment and incorporated self-employment, where

\footnotetext{
7 A few other variables mentioned in the literature that may determine the individual probability of becoming self-employed such as inherited assets and access to funding are not available in the Ruggles et al. (2008) data set and are thus not accounted for.

${ }^{8}$ We do so because some of these individuals - the majority of which are immigrants-also report to be self-employed. This suggests that these observations most likely exhibit a quality bias. We further omit 220 thousand observations that did not indicate the employment status (e.g., employed, self-employed) as well as 4800 unpaid family workers.
} 


$$
y_{i}= \begin{cases}1 & \text { if } i \text { is (incorporated) }) \text { self }- \text { employed } \\ 0 & \text { if } i \text { is employed. }\end{cases}
$$

Observations categorized as employed include private and non-profit wage or salary receivers and federal, state, and local government employees.

We estimate a logit model of the following form.

$$
P\left(y_{i}=1 \mid x_{i}, d_{i}\right)=\frac{\exp \left(\alpha+\beta \mathrm{x}_{\mathrm{i}}+\gamma \mathrm{d}_{\mathrm{i}}\right)}{1+\exp \left(\alpha+\beta x_{i}+\gamma d_{i}\right)}
$$

where vector $x_{i}$ includes age; a dummy for gender $(1=$ male $)$; categorical variables for educational attainment, marital status and proficiency in English; the number of children; and several industry dummies. ${ }^{9} d_{\mathrm{i}}$ includes a dummy variable equal to one for either being an immigrant, for each of the continental origins or for each of the countries of origin, and zero otherwise. ${ }^{10} \mathrm{We}$ cluster standard errors at the group level to account for within-group correlation. Summary statistics shown in Table 6 in the Appendix reveal that self-employed individuals, and in particular the incorporated self-employed, are older and have slightly more children on average; they are more likely to be married; they are less likely to lack fluency in English; and they have higher degrees of education. This is consistent with the previous literature as summarized in Sect. 3. In addition, self-employment is more prevalent in the agricultural, construction, retail, services, transport, and medical sectors. Income as well as income from interest, rent, and dividends is higher among the self-employed, and even more so among the incorporated self-employed.

The table further suggests that self-employment differs considerably across individuals from different regions and countries. We test this empirically by

\footnotetext{
${ }^{9}$ We constructed the industry dummies by aggregating dummy variables for those professions that yielded the largest fraction of self-employed persons. The dummies indicate whether a person works in one of the following occupations: agriculture, building and construction, retail, services, transport, and medical. Finally, we also include a dummy variable for household work. Together, these observations cover about half of the sample.

10 The continental regions are classified as follows. East Asia and Pacific (EAP); Eastern Europe and Central Asia (EECA); Latin America and the Caribbean (LAC); Middle East and North Africa (MENA); North America (NAM); Oceania (OCEA); South Asia (SAS); Sub-Saharan Africa (SSA); and Western Europe (WEU). The results were robust to the inclusion of dummies for dwelling ownership, log investment income, total personal income, state and metropolitan dummies.
}

estimating Eq. (1). The results are reported in Table 7 in the Appendix of this paper. ${ }^{11}$ To summarize, the variation across regions and particularly of individual countries within those regions, is substantial and statistically significant. This is illustrated in Fig. 3. The probability of self-employment is significantly above average for immigrants from the Middle East and North Africa, Western Europe, Canada (not shown in the Figure), and South Asia, while it is below average for immigrants from Sub-Saharan Africa and Latin America. In addition, the dispersion of the marginal effects within regions is high. For instance, the overall probability to become self-employed for individuals from the East Asia and Pacific region is close to zero, but it is quite high (and significantly different from zero) for the South Korean $(6.6 \%)$, while it is low for immigrants from the Philippines $(-6.3 \%) .^{12}$

To investigate the potential role for native entrepreneurial patterns, we test whether home-country self-employment is correlated with immigrant selfemployment. We explore the self-employment decision of both first-generation and subsequent-generation immigrants. As proxies for entrepreneurial activity in the home country, we calculate averages of the two types of self-employment (own-account workers and employers, or employers only $)^{13}$ in total

\footnotetext{
$\overline{11}$ Column (1) of Table 7 reports marginal effects of the dummies for country of origin on the probability of being selfemployed overall, and on the probability of being incorporated self-employed in column (2). Columns (3) and (4) report the marginal effects excluding US natives. One may argue that there may be variation in entrepreneurial behavior within countries. This may be true for some countries such as the USA-where we account for possible differences by including state dummies in our regressions - or Switzerland. However, we believe that in the majority of countries, the institutional and economic factors that are likely to shape an entrepreneurial culture (e.g., taxes, contract enforcement regulations, etc.) are specific to countries rather than to within-country regions.

12 Note that there may be risk of type-1 error with respect to the estimates reported in Fig. 3 and Table 7. In addition, the coefficients will likely be biased so that quantitative interpretations should be handled with care. Nevertheless, they allow us to benchmark our estimates to the previous literature with respect to the direction and an approximate interpretation of the estimates and provide evidence for an overall variation in occupation choices according to different countries of origin of immigrants.

${ }^{13}$ Recall from Sect. 2 that the latter variable refers to employers excluding micro-entrepreneurs and may better fit the incorporated self-employment outcome of the Census sample. We include both of them separately in our baseline regressions in order to test the different influences.
} 
850

A. Lassmann, C. Busch
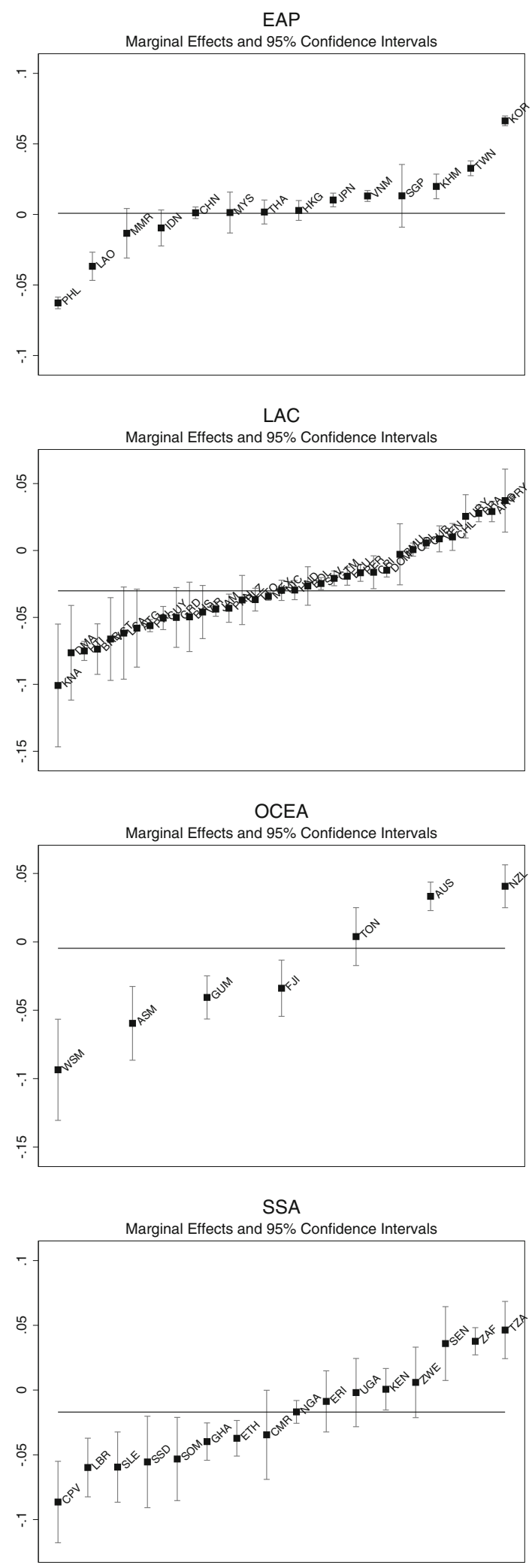

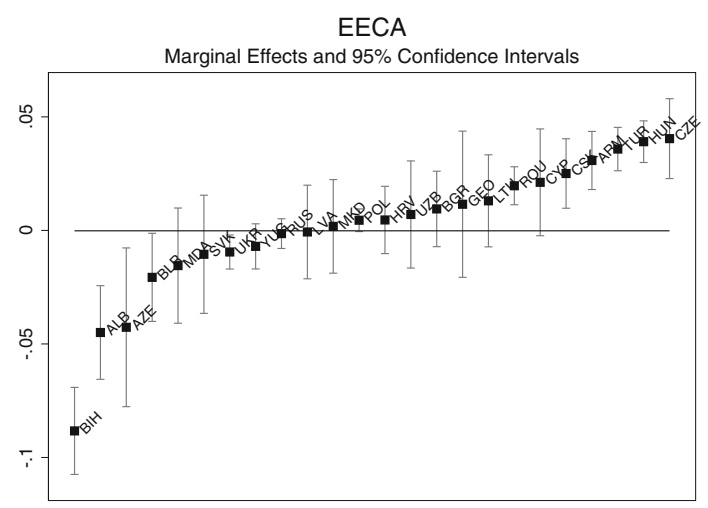

MENA

Marginal Effects and 95\% Confidence Intervals
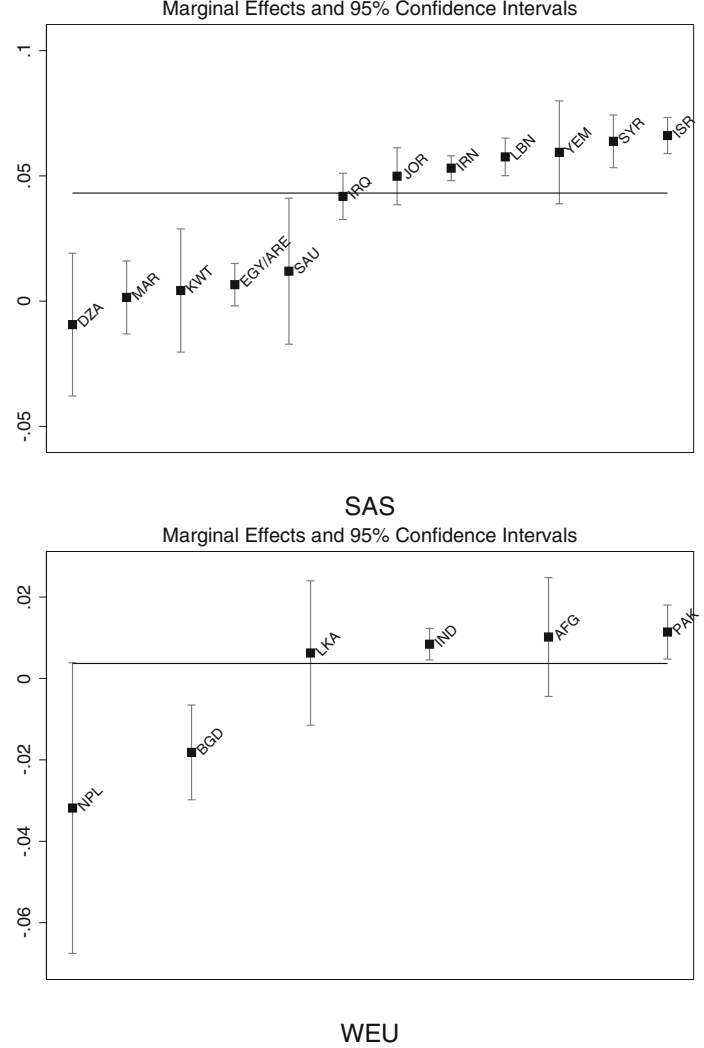

Marginal Effects and 95\% Confidence Intervals

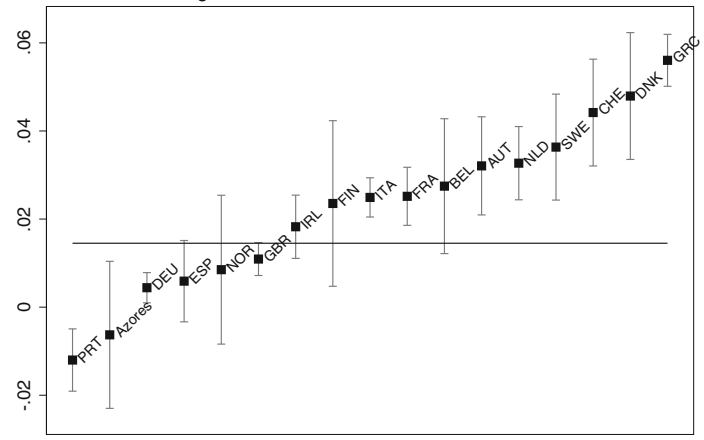

Springer 
४Fig. 3 Estimated differences in self-employment across regions and countries of origin. Notes: Marginal effects from logit regressions with robust standard errors and overall selfemployment as the dependent variable (2000 US Census (Ruggles et al. 2008). Solid horizontal lines represent regional marginal effects. East Asia and Pacific (EAP); Eastern Europe and Central Asia (EECA); Latin America and the Caribbean (LAC); Middle East and North Africa (MENA); North America (NAM); Oceania (OCEA); South Asia (SAS); Sub-Saharan Africa (SSA); and Western Europe (WEU)

active population over the years 1969-2000 using annual employment status data from the ILO Laborstata database for the former. These variables are modeled as continuous variables. The data at hand stem from official national statistical surveys and allow us to distinguish between different sources of manifest entrepreneurial activity. ${ }^{14}$

Our strategy suggests the use of a multilevel analysis that accounts for both within-subject and betweensubject factors (e.g., van Hoorn and Maseland 2010; Stuetzer et al. 2014). In order to do so, we employ a random effects logistic model to account for the hierarchy of the two different levels, the individual level and the country of origin. We further account for other aggregate home-country characteristics that may determine self-employment by calculating variable averages from the World Development Indicators (WDI) from 1960 to $2000 .{ }^{15}$ Few variables in this data set are available over the entire or a large part of the time period, such as GDP per capita, and agricultural employment shares. Since we need a large enough number of country groups to obtain sufficiently precise estimates, this imposes a major restriction on the inclusion of economic and institutional determinants of self-employment over time. For instance, while we

\footnotetext{
$\overline{14}$ We have obtained data about active businesses between 2001 and 2013 in a variety of countries from the GEM database. These data proved qualitatively similar to ILO self-employment shares; hence, they may represent different economic activities compared to the ones in the USA. Results from regressions using these data proved qualitatively similar to the ones using ILO self-employment shares. Note that there has also been increased interest in latent entrepreneurship, or entrepreneurial intentions, across countries (e.g., Blanchflower et al. 2001; Henrekson and Sanandaji 2014; Fitzsimmons and Douglas 2011, GEM database).

15 In the data at hand, there are large differences with respect to the time dimension in which these variables have been reported. This implicates that averages refer to rather recent time periods for some and to longer periods for other countries. To address this, we alternatively matched ten-year averages to the time an immigrant has passed in the USA. The results were robust to this procedure.
}

could account for additional significant institutional determinants as identified in the literature (e.g., Djankov et al. 2002; Klapper et al. 2006; Ardagna and Lusardi 2010), these cover only recent and short time periods and are therefore not suitable in the context of this paper. The following additional variables are chosen based on coverage and previous evidence on the determinants of entrepreneurship: (log) constant 2000 GDP per capita in US dollars; agricultural employment in \% of total employment; unemployment in \% of total labor force; cost of start-up procedures in \% of GNI per capita; the ease of doing business index (ranging from 1 to 179 , where 1 is defined as most business-friendly); the total tax rate in $\%$ of commercial profits; the time required to enforce a contract in days; and the time required to register property in days. Except from GDP per capita and agricultural employment, these variables are not highly correlated among each other ${ }^{16}$ but nevertheless cover important economic and institutional variables relevant for self-employment activity. Table 8 in the Appendix reports summary statistics on these variables across countries. The data generally seem to be of sufficient coverage and quality as is visible from Tables 6 and 8. Overall, the data set includes 79 of the 132 census immigrant countries, in particular the most important ones as measured by the number of immigrants (most notably Mexico). ${ }^{17}$ The mean self-

\footnotetext{
${ }^{16}$ Other possible and available determinants, including age dependency ratios, literacy, or shares of urban population, are highly correlated with GDP per capita. For this reason, we do not include them in the regressions. Finally, we do not account for income inequality-relative returns to skill may provide another potential determinant of entrepreneurial activity, though not necessarily so if the returns to entrepreneurship are lower compared to paid employment (see also Hamilton 2000; Hyytinen et al. 2013)—as no consistent data covering the period and countries included in our data set are available.

17 The strong correlations in Fig. 2 confirm the assumption that coverage and quality are sufficient. However, disadvantages of the data at hand are that some important countries such as China, Russia, India, and Cuba are unfortunately missing entirely, and the data include a few suspicious observations. For instance, the reported agricultural employment shares of Argentina and Peru are low. In addition, the unemployment rates of countries such as Bangladesh, Cambodia, Cameroon, Mexico, or Vietnam are very low. This could be due to either low data quality or-and we consider this explanation more likely-to the fact that (because of the absence of social security benefits) job-seeking individuals do not report unemployment or are pushed into selfemployment. We also drop Eritrea from the sample regarding the employer share. This country reports one of the highest employer shares, which may be due to measurement error.
} 
employment share and employer share amount to 25.1 and $4.7 \%$, respectively. Average GDP per capita is 6109 USD, and the average percentage of agricultural employment is 26.2. The countries with the lowest and highest average self-employment shares are Slovakia $(6.8 \%)$ and Cameroon (68.6\%). The employer share is lowest on average in Vietnam $(0.2 \%)$ and highest in Egypt (16\%).

In order to analyze the persistence of home-country self-employment and to shed light on potential cultural differences in entrepreneurial behavior, we refer to the ancestry of the individual. ${ }^{18}$ We calculate mean selfemployment ratios from the UN Demographic Yearbooks of the years 1949/50, 1955, and 1964 and make use of the earliest home-country data available to capture the environment of foreign ancestors. ${ }^{19}$ In studying the self-employment decision of individuals with foreign ancestry, we control for GDP per capita, averaged over the years 1960 to $1965 .{ }^{20}$ Together with self-employment and employer shares in ancestor countries of origin, descriptive statistics are shown in Table 9 in the Appendix of this paper. The data cover 61 of the 132 US Census ancestor countries. The sample averages correspond to $18.8 \%$ for the selfemployment share, to $2.8 \%$ for the employer share and to 7660 for GDP per capita (in constant 2000 USD). Average self-employment shares are lowest in Malaysia $(3.8 \%)$ and highest in Pakistan $(81.9 \%)$. Average employer shares are lowest in Fiji $(0.2 \%)$ and highest in Morocco (18.8\%).

To test the relationship between self-employment in the home country $j$ of individual $i$ and the country of

\footnotetext{
$\overline{18}$ Individuals may indicate several-ranked-ancestor countries. This has the advantage that one principal ancestry is given. The disadvantage is that it does not clearly allow us to distinguish between generations in the USA. We therefore have to bear in mind that this potentially produces a bias against finding significant results. Note further that this results in a larger number of observations but not of country groups.

19 Note that the figures are based on country censuses that may refer to earlier years. The 1949/50 Yearbook contains only overall self-employment. To our knowledge, these figures are the earliest figures available after World War II. Since major immigration occurred after the war, we consider this period an appropriate starting point to our analysis.

20 These are the earliest years available in the data set at hand. While one could think of sources including earlier figures for GDP, we consider the period at hand to be consistent with the data on self-employment in terms of the time dimension.
}

immigration, the following random effects logit equation is estimated:

$$
P\left(y_{\mathrm{ji}}=1 \mid x_{\mathrm{ji}}, z_{\mathrm{ji}}, c_{j}\right)=\frac{\exp \left(\alpha+\beta \mathrm{x}_{\mathrm{ji}}+\delta \mathrm{z}_{\mathrm{ji}}+\mathrm{c}_{\mathrm{j}}\right)}{1+\exp \left(\alpha+\beta x_{\mathrm{ji}}+\delta z_{\mathrm{ji}}+c_{j}\right)}
$$

where $y_{\mathrm{ji}}$ and $x_{\mathrm{ji}}$ are now double-indexed but are else defined as in Eq. (1); $z_{\mathrm{ji}}$ is the additional vector of home-country variables, and we assume an unobserved random home-country effect $c_{\mathrm{j}}$. We additionally include US state dummies in $x_{\mathrm{ij}}$ in order to account for regional differences across the country. We do not scale self-employment rates to those of US natives, but rather omit all US observations from the regressions, thereby taking into account that including the latter leads to capturing the differences between immigrants and US natives (Fairlie and Meyer 1996). Results are presented in the following section.

\section{Empirical results}

\subsection{Cross-country differences in self-employment} and self-employment in the USA

This section presents the results on the relationship between self-employment in the home country and the country of immigration from estimating Eq. (2). They are shown in Tables 1, 2, and 3. The tables are structured as follows. The dependent variable is overall self-employment in Tables 1 and 3 and incorporated self-employment in Table 2 . The key variable of interest is the self-employment share in the country of origin in Table 1 and the employer share in the country of origin in Tables 2 and 3. Column (1) includes this variable only, while columns (2-3) control for additional determinants in the country of origin separately. Column (4) includes all variables except agricultural employment, which is strongly correlated with GDP per capita.

We may summarize as follows. The marginal effect of home-country self-employment shares on the likelihood to become self-employed in the USA as shown in Table 1 is negative and significant. It amounts to -0.081 in column (1) and with the inclusion of further country-level variables-increases to -0.121 according to column (4). Except for the time required to register property, the 
Table 1 US immigrant and country of origin self-employment share

\begin{tabular}{|c|c|c|c|c|}
\hline \multirow[t]{2}{*}{ Dependent variable } & \multicolumn{4}{|c|}{ Overall self-employment } \\
\hline & (1) & (2) & (3) & (4) \\
\hline Self-employment share & $-0.081 * * *$ & $-0.068^{*}$ & $-0.118 * * *$ & $-0.121 * * *$ \\
\hline (\% of active population) & $(0.027)$ & $(0.041)$ & $(0.039)$ & $(0.034)$ \\
\hline Log GDP per capita & & $0.008 * *$ & & $0.011 * * *$ \\
\hline (constant 2000 USD) & & $(0.003)$ & & $(0.003)$ \\
\hline Agricultural employment & & & $-1.54 \mathrm{e}-04$ & \\
\hline (\% of total employment) & & & $(2.16 \mathrm{e}-04)$ & \\
\hline Unemployment & & & & $-0.006 * * *$ \\
\hline (\% of total labor force) & & & & $(0.001)$ \\
\hline Cost of start-up prodedures & & & & $-2.34 \mathrm{e}-04 * * *$ \\
\hline (\% of GNI per capita) & & & & $(8.47 \mathrm{e}-05)$ \\
\hline Ease of doing business index & & & & $2.89 \mathrm{e}-04 * * *$ \\
\hline$(1=$ most business-friendly $)$ & & & & $(7.19 \mathrm{e}-05)$ \\
\hline Tax rate & & & & $0.001 * * *$ \\
\hline (\% of commercial profits) & & & & $(1.96 \mathrm{e}-04)$ \\
\hline Contract enforcement & & & & $-3.99 \mathrm{e}-05^{* * *}$ \\
\hline (Time required in days) & & & & $(8.87 \mathrm{e}-06)$ \\
\hline Property registration & & & & $4.59 \mathrm{e}-05$ \\
\hline (Time required in days) & & & & $(3.99 \mathrm{e}-05)$ \\
\hline Number of obs. & 679,094 & 614,180 & 613,667 & 612,595 \\
\hline Number of groups & 66 & 55 & 54 & 54 \\
\hline Mean no. of obs. per group & 10,289 & 11,167 & 11,364 & 11,344 \\
\hline
\end{tabular}

Marginal effects from random effects logit regressions. Estimation is based on the adaptive Gaussian-Hermite approximation of the likelihood with five integration points. The dependent variable is a dummy for being self-employed (immigrants only). The estimations include the following variables not reported above: age, gender, number of children, dummies for marital status, education, proficiency in English, industry of employment, and state dummies (Ruggles et al. 2008). Other control variables: selfemployment in active population, average 1969-2000 (ILO Laborsta); all other variables: World Development Indicators, averages 1960-2000

$* * *, * *, *$ denote statistical significance at the 1,5 , and $10 \%$ level, respectively

institutional variables carry a negative sign and are significant as well (e.g., Kaplan et al. 2011; Bruhn 2011). They are, however, negligible in size. Note that there may be at least some collinearity between the variables capturing the institutional entrepreneurial environment and the self-employment share in a country such that the latter variable may capture some of the effects of the institutional characteristics. Home-country GDP is significant and positive, with the marginal effect amounting to 0.011 (column 4), pointing to the relevance of endowment factors. Recall from Fig. 2 that the self-employment share is higher in less developed countries. A possible interpretation for the negative sign of this variable on the outcome in the USA is that self-employment may indeed capture entirely different activities in different countries and has therefore limited informative value with respect to wealth-creating entrepreneurial behavior.

The marginal effect of an increase in the employer share by $1 \%$ point on the probability to become incorporated self-employed is significant and positive and amounts to 0.139 as reported in column (1) of Table 2. It becomes slightly lower once GDP and additional variables are accounted for as shown in columns (2) and (4). The employer share becomes insignificant with the inclusion of institutional factors. None of the control variables but GDP and unemployment-which possibly indicates that endowment factors are able to capture a potential positive effect of home-country entrepreneurial activity and institutions-are significantly different from zero, and even those two are only weakly significant. Note, however, 
Table 2 US immigrant incorporated self-employment and country of origin employer share

\begin{tabular}{|c|c|c|c|c|}
\hline \multirow[t]{2}{*}{ Dependent variable } & \multicolumn{4}{|c|}{ Incorporated self-employment } \\
\hline & (1) & (2) & (3) & (4) \\
\hline Employer share & $0.139 * *$ & $0.093 *$ & $0.137 * *$ & 0.022 \\
\hline (\% of active population) & $(0.054)$ & $(0.054)$ & $(0.069)$ & $(0.076)$ \\
\hline Log GDP per capita & & $0.004 * * *$ & & $0.004 *$ \\
\hline (constant 2000 USD) & & $(0.001)$ & & $(0.002)$ \\
\hline Agricultural employment & & & $-8.12 \mathrm{e}-05$ & \\
\hline (\% of total employment) & & & $(1.10 \mathrm{e}-04)$ & \\
\hline Unemployment & & & & $-0.001 *$ \\
\hline (\% of total labor force) & & & & $(4.76 \mathrm{e}-04)$ \\
\hline Cost of start-up prodedures & & & & $1.95 \mathrm{e}-05$ \\
\hline ( $\%$ of GNI per capita) & & & & $(5.79 \mathrm{e}-05)$ \\
\hline Ease of doing business index & & & & $-5.75 \mathrm{e}-05$ \\
\hline$(1=$ most business-friendly) & & & & $(7.06 \mathrm{e}-05)$ \\
\hline Tax rate & & & & $1.77 \mathrm{e}-04$ \\
\hline (\% of commercial profits) & & & & $(1.27 \mathrm{e}-04)$ \\
\hline Contract enforcement & & & & $-3.55 \mathrm{e}-06$ \\
\hline (Time required in days) & & & & $(7.06 \mathrm{e}-06)$ \\
\hline Property registration & & & & $3.17 \mathrm{e}-06$ \\
\hline (Time required in days) & & & & $(2.84 \mathrm{e}-05)$ \\
\hline Number of obs. & 637,117 & 578,165 & 578,870 & 577,122 \\
\hline Number of groups & 69 & 57 & 58 & 57 \\
\hline Mean no. of obs. per group & 9234 & 10,143 & 9981 & 10,125 \\
\hline
\end{tabular}

Marginal effects from random effects logit regressions. Estimation is based on the adaptive Gaussian-Hermite approximation of the likelihood with five integration points. The dependent variable is a dummy for being incorporated self-employed (immigrants only). The estimations include the following variables not reported above: age, gender, number of children, dummies for marital status, education, proficiency in English, industry of employment, and state dummies (Ruggles et al. 2008). Other control variables: employers in active population, average 1969-2000 (ILO Laborsta); all other variables: World Development Indicators, averages 1960-2000

$* * *, * *, *$ denote statistical significance at the 1,5 , and $10 \%$ level, respectively

that precision is lost as the addition of control variables decreases the number of countries $j$ in general. Furthermore, the precision of the group-level results should be inferior to the individual-level results due to the fact that the number of groups is rather small. This reduces the variation in the data at hand and should rather increase the risk that we find insignificant results (type-2 error). Hence, while there may be an increased probability for type-1 error with respect to some variables, this should not be the case for the group-level variables.

The marginal effect of home-country employer shares on overall self-employment reported in Table 3 is positive and amounts to 0.190 . The results in column (2) suggest a significant impact of GDP and a negative sign with respect to the employer share. This holds with the inclusion of additional control variables in column (4), which suggests further that most of the institutional factors are weakly but significantly related to the choice of becoming overall self-employed.

Overall, the addition of home-country GPD, agricultural employment, and institutional characteristics seems to add little to the model. However, a likelihood ratio statistic of a restricted model based on homecountry self-employment only versus models that include additional home-country characteristics yields a significant improvement in the model fit. We may obtain more systematic insights with respect to native self-employment shares by analyzing the group variance for different models. To summarize, we find that only $4.1 \%$ in the propensity to become overall self-employed (the first dependent variable of interest) can be attributed 
Table 3 US immigrant self-employment and country of origin employer share

\begin{tabular}{|c|c|c|c|c|}
\hline \multirow[t]{2}{*}{ Dependent variable } & \multicolumn{4}{|c|}{ Overall self-employment } \\
\hline & (1) & (2) & (3) & (4) \\
\hline Employer share & $0.190 * *$ & $0.266 * *$ & 0.166 & $-0.357 * * *$ \\
\hline (\% of active population) & $(0.075)$ & $(0.133)$ & $(0.142)$ & $(0.112)$ \\
\hline Log GDP per capita & & $0.016^{* * *}$ & & $0.019 * * *$ \\
\hline (constant 2000 USD) & & $(0.003)$ & & $(0.003)$ \\
\hline Agricultural employment & & & $-2.87 \mathrm{e}-04$ & \\
\hline (\% of total employment) & & & $(2.38-04)$ & \\
\hline Unemployment & & & & $-0.005 * * *$ \\
\hline (\% of total labor force) & & & & $(5.63 \mathrm{e}-04)$ \\
\hline Cost of start-up prodedures & & & & $-1.37 \mathrm{e}-04$ \\
\hline (\% of GNI per capita) & & & & $(8.96 \mathrm{e}-05)$ \\
\hline Ease of doing business index & & & & $1.48 \mathrm{e}-04 * *$ \\
\hline (1=most business-friendly) & & & & $(7.48 \mathrm{e}-05)$ \\
\hline Tax rate & & & & $7.87 \mathrm{e}-04 * * *$ \\
\hline (\% of commercial profits) & & & & $(2.08 \mathrm{e}-04)$ \\
\hline Contract enforcement & & & & $-4.40 \mathrm{e}-05^{* * *}$ \\
\hline (Time required in days) & & & & $(9.93 e-06)$ \\
\hline Property registration & & & & $8.16 \mathrm{e}-05^{* *}$ \\
\hline (Time required in days) & & & & $(4.00 \mathrm{e}-05)$ \\
\hline Number of obs. & 682,481 & 616,835 & 617,567 & 615,763 \\
\hline Number of groups & 69 & 57 & 57 & 56 \\
\hline Mean no. of obs. per group & 9891 & 10,822 & 10,648 & 10,986 \\
\hline
\end{tabular}

Marginal effects from random effects logit regressions. Estimation is based on the adaptive Gaussian-Hermite approximation of the likelihood with five integration points. The dependent variable is a dummy for being self-employed (immigrants only). The estimations include the following variables not reported above: age, gender, number of children, dummies for marital status, education, proficiency in English, industry of employment, and state dummies (Ruggles et al. 2008). Other control variables: employers in active population, average 1969-2000 (ILO Laborsta); all other variables: World Development Indicators, averages 1960-2000

$* * *, * *, *$ denote statistical significance at the 1,5 , and $10 \%$ level, respectively

to the group level (country of origin) in a regression including solely baseline individual-level variables; hence, unobserved $\mathrm{COO}$ characteristics account for $4.1 \%$ of the propensity for different individuals. When including the home-country self-employment share, the intra-class correlation coefficient (ICC) decreases to 0.036 , attenuating the between-group variation to some extent. When we additionally account for GDP, the ICC decreases to 0.03 . The respective figure is 0.025 if we also include home-country institutions. On the other hand, when we include only the self-employment share in the regressions but exclude individual-level variables, it amounts to 0.049 , indicating that the individual-level covariates also attenuate the association between and within groups. Accordingly, the degree to which the between- and within-school variation can be accounted for by individual-level factors is not much larger than the one due to the inclusion of the self-employment share (or other aggregate variables). This is interesting because the chosen individual-level variables have been attributed a high weight in determining entrepreneurial choices throughout the previous literature. Similar figures hold for regressions involving incorporated self-employment as the dependent variable and the employer share as an independent variable: The ICC is $5.9 \%$ in a regression with individual-level variables only; it is 0.054 once we include the home-country employer share; 0.042 when we include GDP, and 0.035 once we include institutions; it amounts to 0.072 if we include the employer share as the only covariate (apart from a constant) but exclude baseline individual-level variables. The ICC for the USA are slightly lower than 
ones estimated for Sweden, where the explained variance amounts to $7.6 \%$ for men, and to $9.8 \%$ for women (see Ohlsson et al. 2012).

\subsection{Second-generation self-employment}

The patterns found in the previous subsection may reflect the fact that individuals are subject to capturing factors other than those referring to cultural entrepreneurial values. This is due to bias from self-selection and shocks specific to immigration (see Fernández 2008) as highlighted in Sect. $2 .^{21}$

Recall further that immigrants are subject to pushand pull-factors that may distort the self-employment decision. To address this issue, we test the robustness of our results by studying the entrepreneurial activity of subsequent generations of immigrants. The results are presented in Table 4. The table is structured in the following way. The dependent variable is overall selfemployment in columns (1-2) and (5-6) and incorporated self-employment in columns (3-4). The variable of interest is the home-country self-employment share in columns (1) and (2) and employer share in columns (3-6). Regressions are run with and without controlling for GDP per capita. The marginal effect is negative and insignificant with respect to self-employment shares in columns (1) and (2). It is positive and significant with respect to employer shares and amounts to 0.115 on incorporated self-employment in column (3) and to 0.315 on overall self-employment in

\footnotetext{
$\overline{21}$ A common assertion states that immigrants arrive with a set of cultural values and behaviors different from those in the destination country and are prone to shocks due to language, new institutions, etc. Although it has been shown that transplanted behavior is persistent, it is possible that institutional factors and cultural norms in the country of immigration become more important. As a consequence, home-country effects may fade over time. Although we are not able to identify assimilation effects using the cross-sectional data at hand, we may obtain a tentative idea by examining the evolution of entrepreneurial activity of immigrants over time using interaction terms for the self-employment share with the discrete duration of residence in the USA. Appendix Fig. 5 shows the marginal effect of home-country self-employment shares evaluated at different intervals of years an immigrant has passed in the USA (i.e., the effect of a change in home-country selfemployment shares by 1 percentage points with years in the US held constant at different values). The results are qualitatively similar to the ones in Sect. 5.1, with marginal effects that are increasing in the duration of stay in the USA.
}

column (5). The estimated marginal effects become insignificant once GDP is taken into account (see columns 4 and 6). The table suggests that GDP per capita is partly a weak driver of the occupation choice. Note that this approach risks finding no effect or an attenuated effect on the variable of interest due to assimilation. Indeed, the results of Table 4 do not provide robust confirming evidence of a persistent impact of native entrepreneurial culture on the selfemployment decision of individuals.

\subsection{Home-country self-employment and GDP}

Oyelere and Belton (2012) show that the probability of becoming self-employed in the USA increases with higher levels of development. We therefore want to take into account the possibility of observing higher home-country effects when income is larger at the same time. We allow for possible nonlinear patterns by interacting home-country selfemployment with GDP per capita. The marginal effects evaluated at different percentiles of GDP per capita are shown in the panel to the left-hand side of Fig. 4. The slope of home-country self-employment is more or less constant in income and insignificant over the entire distribution in upper left figure. The pattern in the middle left figure-illustrating the relationship between the incorporated self-employment propensity and home-country employer shares at different income levels-is in line with Oyelere and Belton (2012), i.e., the effect of the employer share is increasing in home-country GDP. The marginal effects are significant in lower-income percentiles, where they are negative. In addition, they are significantly different from zero at higherincome percentiles, where the effects become positive, i.e., the home-country effect becomes more important with increasing income. A possible explanation for the patterns found could be that initial endowments play an important role in determining the choice of self-employment in the home country (see Evans and Jovanovic 1989). This result points in the direction of the one found in Table 2 and may indicate further evidence for the role of endowments in the self-employment choice of immigrants in the US different entrepreneurial actions. Finally, the pattern is the same regarding the relationship between overall self-employment and home-country employer shares. 
Table 4 Second-generation US and country of origin self-employment share

\begin{tabular}{|c|c|c|c|c|c|c|}
\hline \multirow[t]{2}{*}{ Dependent variable } & \multicolumn{2}{|c|}{ Overall self-emp. } & \multicolumn{2}{|c|}{ Incorp. self-emp. } & \multicolumn{2}{|c|}{ Overall self-emp. } \\
\hline & (1) & (2) & (3) & (4) & (5) & (6) \\
\hline $\begin{array}{l}\text { Self-emp. share } \\
\text { (\% of active pop.) }\end{array}$ & $\begin{array}{c}-0.049 \\
(0.037)\end{array}$ & $\begin{array}{c}-0.018 \\
(0.043)\end{array}$ & & & & \\
\hline $\begin{array}{l}\text { Employer share } \\
\text { (\% of active pop.) }\end{array}$ & & & $\begin{array}{l}0.115^{*} \\
(0.060)\end{array}$ & $\begin{array}{c}0.049 \\
(0.068)\end{array}$ & $\begin{array}{l}0.315^{* *} \\
(0.130)\end{array}$ & $\begin{array}{c}0.161 \\
(0.119)\end{array}$ \\
\hline $\begin{array}{l}\text { Log GDP p.c. } \\
\text { (constant USD) }\end{array}$ & & $\begin{array}{c}0.010^{*} \\
(0.005)\end{array}$ & & $\begin{array}{c}0.004 \\
(0.002)\end{array}$ & & $\begin{array}{r}0.008^{*} \\
(0.005)\end{array}$ \\
\hline Number of obs. & 645,836 & 538,050 & 489,682 & 447,958 & 521,342 & 477,449 \\
\hline Number of groups & 61 & 46 & 46 & 39 & 46 & 39 \\
\hline Mean obs. per group & 10,588 & 11,697 & 10,645 & 11,486 & 11,334 & 12,242 \\
\hline
\end{tabular}

Marginal effects from random effects logit regressions. Estimation is based on the adaptive Gaussian-Hermite approximation of the likelihood with five integration points. The dependent variable is a dummy for being (incorporated) self-employed (individuals reporting foreign ancestry only). The estimations include the following variables not reported above: age, gender, number of children, dummies for marital status, education, proficiency in English, and industry of employment (Ruggles et al. 2008). Other control variables: sum of own-account workers and employers in active population (self-employment share) and employers in active population (employer share), average 1950, 1955 and 1964 (UN Demographic Yearbooks); GDP per capita (constant 2000 USD): World Development Indicators, averages 1960-1965

$* * *, * *, *$ denote statistical significance at the 1,5 , and $10 \%$ level, respectively

Evaluating the respective home-country self-employment share at different percentiles of homecountry GDP for second-generation individuals as shown in the right-hand side of Fig. 4 yields patterns that are qualitatively similar compared to the ones in the left-hand side of the figure. Again, they confirm no significant influence of home-country entrepreneurial patterns on occupation choices that persists across generations.

\section{Conclusions}

There is a large literature showing that immigrant selfemployment differs from US native self-employment. These differences remain after accounting for a wide variety of individual characteristics, but evidence of a relationship between self-employment in the country of origin and the country of immigration has been so far inconclusive. By accounting for different definitions of entrepreneurial activity, this paper provides a potential explanation to this puzzle. We analyze two measures of entrepreneurial choices in the USA, where we distinguish between incorporated and non-incorporated selfemployed individuals using individual-level US Census data, as well as self-employment shares and employer shares in the active population of immigrants' native countries. We find that the relationship between self-employment in the USA and the home country is negative and significant on the one hand. On the other hand, the relationship between self-employment in the US and home-country employer shares is positive but the effect is only significant at higher levels of income in the country of origin. We interpret the first finding as a consequence of the negative correlation between home-country self-employment and income. Overall self-employment seems to capture underdevelopment and the prevalence of large subsistence sectors. The employer share is positively correlated with GDP per capita and is in our view a more appropriate proxy for entrepreneurial activity that creates employment and innovation. These results are robust to specifications accounting for economic and institutional home-country determinants but not to studying the behavior of subsequent generations of immigrants; hence, we cannot confirm the persistence of a native entrepreneurial culture. The increased availability of micro-level entrepreneurial data may provide a foundation for future research regarding a potential causal effect of cultural traits on entrepreneurial choices as well as the channels through which such values are transmitted. 

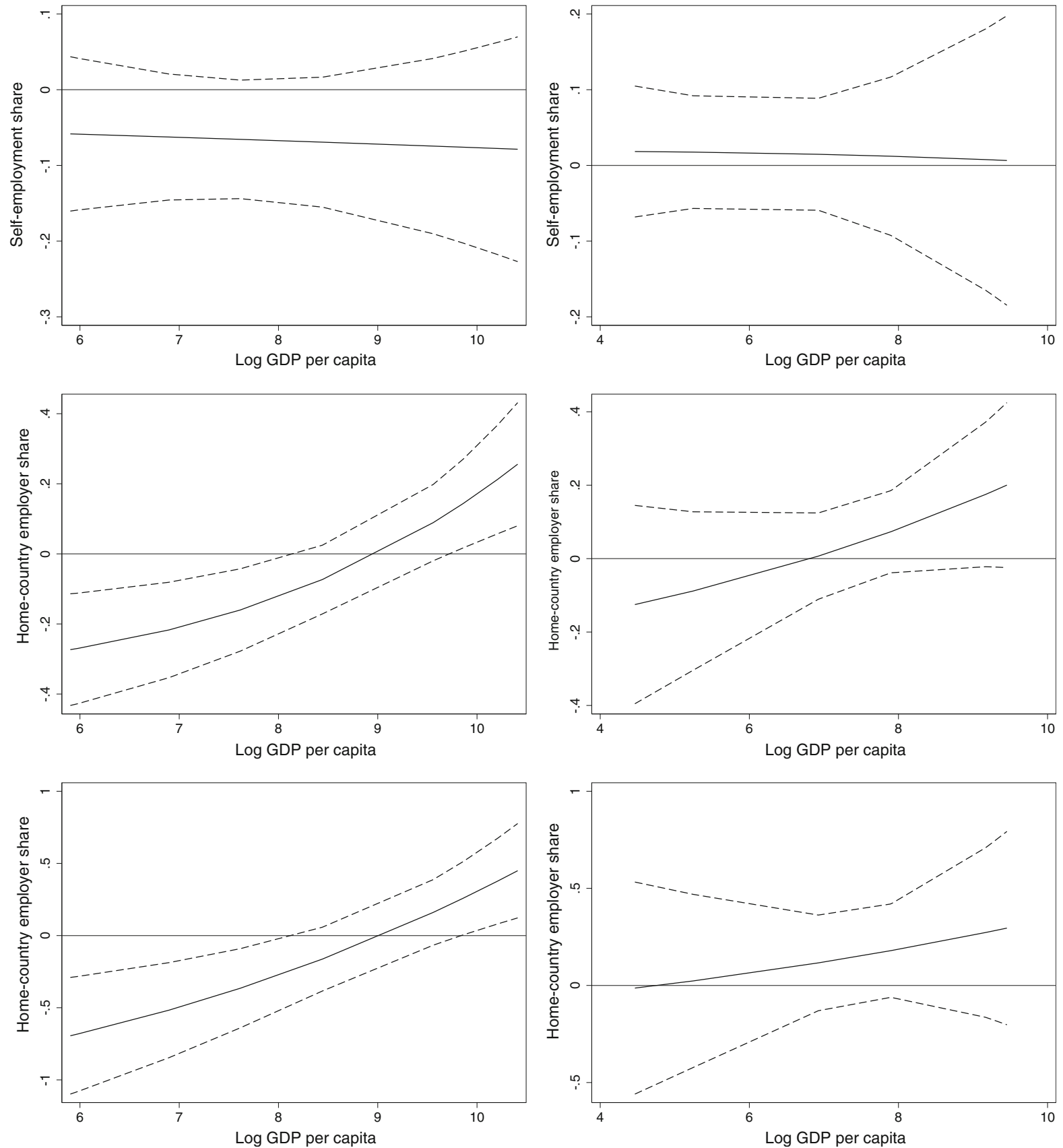

Fig. 4 Home-country self-employment share and log GDP per capita. Notes: Marginal effects and $95 \%$ c.i. from random effects logit regressions evaluated at different levels of homecountry GDP per capita, other variables at sample means. Firstgeneration immigrants on the left-hand side panel (LHS), second-generation individuals on the right-hand side (RHS). The dependent variable is a dummy for being self-employed (immigrants only) in the first and third panel, and for being incorporated self-employed in the second panel. The estimations include the following variables not reported above: age, gender, number of children, dummies for marital status,

education, proficiency in English and industry of employment, and state dummies (Ruggles et al. 2008). Other control variables (LHS): self-employment and employer share in total active population: ILO Laborsta, average 1969-2000; other variables: World Development Indicators, averages 1960-2000; (RHS): sum of own-account workers and employers in active population (self-employment share) and employers in active population (employer share), average 1950, 1955 and 1964 (UN Demographic Yearbooks); GDP per capita: World Development Indicators, averages 1960-1965 
Acknowledgments We would like to thank Silvia Ardagna for a fruitful discussion at the World Bank Conference on Entrepreneurship and Growth. We are grateful to Matthias Bannert for providing generous advice regarding computational issues. We also received helpful comments from Sule Akkoyunlu, Peter Egger, Richard Jong-A-Ping, Leora Klapper, Sarah Lein, Nora Strecker, seminar participants at the World Bank Conference on Entrepreneurship and Growth, the Beyond Basic Questions Seminar in Zurich, the KOF Brown
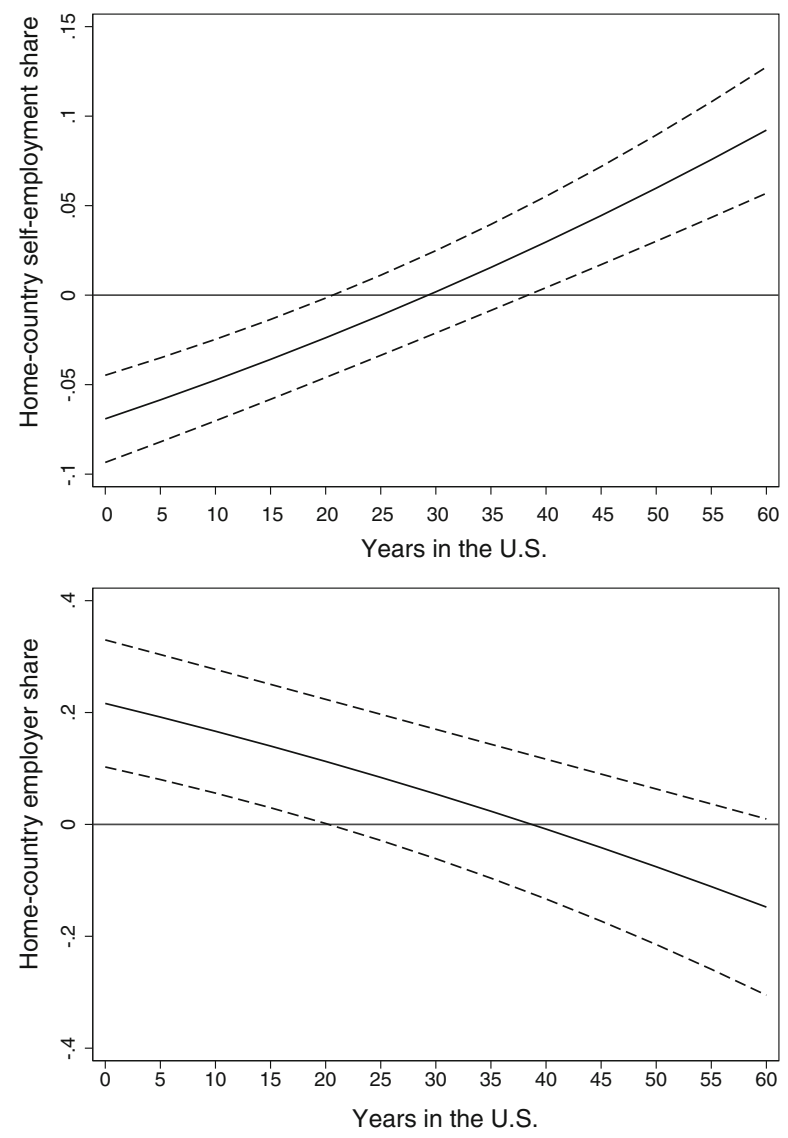

Fig. 5 Home-country self-employment share and years passed in the USA. Notes: Marginal effects and $95 \%$ confidence intervals from logit regressions with clustered standard errors evaluated at different years an immigrant has spent in the USA, other variables at sample means. The dependent variable is a dummy for being (incorporated) self-employed (immigrants
Bag Seminar, and the Spring Meeting of Young Economists in Istanbul, and two anonymous reviewers.

\section{Appendix}

See Fig. 5; Tables 5, 6, 7, 8 and 9.

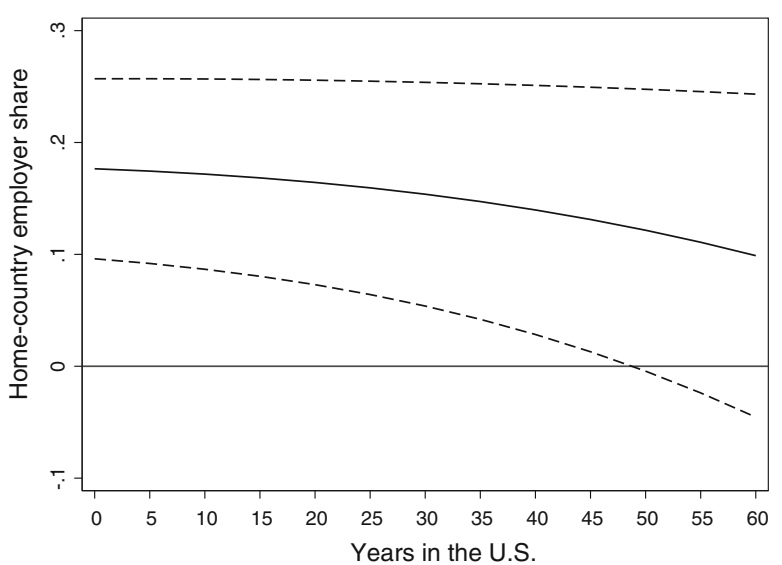

only). The estimations include the following variables not reported above: age, age squared, gender, number of children, dummies for marital status, education, proficiency in English, industry of employment, and state dummies (Ruggles et al. 2008). Self-employment and employer share in total active population: ILO Laborsta, average 1969-2000 
Table 5 Country correspondence to ISO 3166(-1) ALPHA-3 country codes and continental codes

\begin{tabular}{|c|c|c|c|c|c|}
\hline Country name & ISO 3166 (ALPHA-3) & Contin. code & Country name & ISO 3166 (ALPHA-3) & Contin. code \\
\hline China & $\mathrm{CHN}$ & EAP & Paraguay & PRY & LAC \\
\hline Hong Kong & HKG & EAP & El Salvador & SLV & LAC \\
\hline Indonesia & IDN & EAP & Trinidad and Tobago & TTO & LAC \\
\hline Japan & JPN & EAP & Uruguay & URY & LAC \\
\hline Cambodia & KHM & EAP & St. Vincent & VCI & LAC \\
\hline South Korea & KOR & EAP & Venezuela & VEN & LAC \\
\hline Laos & $\mathrm{LAO}$ & EAP & US Virgin Islands & VIR & LAC \\
\hline Burma (Myanmar) & MMR & EAP & Algeria & DZA & MENA \\
\hline Malaysia & MYS & EAP & Egypt/United Arab Rep. & EGY & MENA \\
\hline Philippines & PHL & EAP & Iran & IRN & MENA \\
\hline Singapore & SGP & EAP & Iraq & IRQ & MENA \\
\hline Thailand & THA & EAP & Israel & ISR & MENA \\
\hline Taiwan & TWN & EAP & Jordan & JOR & MENA \\
\hline Vietnam & VNM & EAP & Kuwait & KWT & MENA \\
\hline Albania & ALB & EECA & Lebanon & LBN & MENA \\
\hline Armenia & ARM & EECA & Morocco & MAR & MENA \\
\hline Azerbaijan & AZE & EECA & Saudi Arabia & SAU & MENA \\
\hline Bulgaria & BGR & EECA & Syria & SYR & MENA \\
\hline Bosnia & $\mathrm{BIH}$ & EECA & Yemen Arab Republic & YEM & MENA \\
\hline Byelorussia & BLR & EECA & Canada & CAN & NAM \\
\hline Czechoslovakia & CSK & EECA & American Samoa & ASM & OCEA \\
\hline Cyprus & CYP & EECA & Australia & AUS & OCEA \\
\hline Czech Republic & $\mathrm{CZE}$ & EECA & Fiji & FJI & OCEA \\
\hline Georgia & GEO & EECA & Guam & GUM & OCEA \\
\hline Croatia & HRV & EECA & New Zealand & NZL & OCEA \\
\hline Hungary & HUN & EECA & Tonga & TON & OCEA \\
\hline Lithuania & LTU & EECA & Western Samoa & WSM & OCEA \\
\hline Latvia & LVA & EECA & Afghanistan & AFG & SAS \\
\hline Moldavia & MDA & EECA & Bangladesh & BGD & SAS \\
\hline Macedonia & MKD & EECA & India & IND & SAS \\
\hline Poland & POL & EECA & Sri Lanka (Ceylon) & LKA & SAS \\
\hline Romania & ROU & EECA & Nepal & NPL & SAS \\
\hline Other USSR/Russia & RUS & EECA & Pakistan & PAK & SAS \\
\hline Slovakia & SVK & EECA & Cameroon & CMR & SSA \\
\hline Turkey & TUR & EECA & Cape Verde & CPV & SSA \\
\hline Ukraine & UKR & EECA & Eritrea & ERI & SSA \\
\hline Uzbekistan & UZB & EECA & Ethiopia & ETH & SSA \\
\hline Yugoslavia & YUG & EECA & Ghana & GHA & SSA \\
\hline Argentina & ARG & LAC & Kenya & KEN & SSA \\
\hline Antigua-Barbuda & ATG & LAC & Liberia & LBR & SSA \\
\hline Bahamas & BHS & LAC & Nigeria & NGA & SSA \\
\hline Belize/British Honduras & BLZ & LAC & Senegal & SEN & SSA \\
\hline Bermuda & $\mathrm{BMU}$ & LAC & Sierra Leone & SLE & SSA \\
\hline Bolivia & BOL & LAC & Somalia & SOM & SSA \\
\hline Brazil & BRA & LAC & Sudan & SSD & SSA \\
\hline
\end{tabular}


Table 5 continued

\begin{tabular}{|c|c|c|c|c|c|}
\hline Country name & ISO 3166 (ALPHA-3) & Contin. code & Country name & ISO 3166 (ALPHA-3) & Contin. code \\
\hline Barbados & $\mathrm{BRB}$ & LAC & Tanzania & TZA & SSA \\
\hline Chile & $\mathrm{CHL}$ & LAC & Uganda & UGA & SSA \\
\hline Colombia & $\mathrm{COL}$ & LAC & South Africa (Union of) & $\mathrm{ZAF}$ & SSA \\
\hline Costa Rica & CRI & LAC & Zimbabwe & ZWE & SSA \\
\hline Cuba & CUB & LAC & Austria & AUT & WEU \\
\hline Dominica & DMA & LAC & Belgium & BEL & WEU \\
\hline Dominican Republic & DOM & LAC & Switzerland & $\mathrm{CHE}$ & WEU \\
\hline Ecuador & $\mathrm{ECU}$ & LAC & Germany & DEU & WEU \\
\hline Grenada & GRD & LAC & Denmark & DNK & WEU \\
\hline Guatemala & GTM & LAC & Spain & ESP & WEU \\
\hline Guyana/British Guiana & GUY & LAC & Finland & FIN & WEU \\
\hline Honduras & HND & LAC & France & FRA & WEU \\
\hline Haiti & HTI & LAC & England & GBR & WEU \\
\hline Jamaica & JAM & LAC & Greece & GRC & WEU \\
\hline St. Kitts-Nevis & KNA & LAC & Ireland & IRL & WEU \\
\hline St. Lucia & LCA & LAC & Italy & ITA & WEU \\
\hline Mexico & MEX & LAC & Netherlands & NLD & WEU \\
\hline Nicaragua & NIC & LAC & Norway & NOR & WEU \\
\hline Panama & PAN & LAC & Portugal & PRT & WEU \\
\hline Peru & PER & LAC & Sweden & SWE & WEU \\
\hline Puerto Rico & PRI & LAC & Azores & & WEU \\
\hline
\end{tabular}

Table 6 Descriptive statistics of the 2000 US Census

\begin{tabular}{|c|c|c|c|c|c|c|c|}
\hline & Obs. & $\begin{array}{l}\text { Overall } \\
\text { self-emp. }\end{array}$ & $\begin{array}{l}\text { Incorp. } \\
\text { self-emp. }\end{array}$ & & Obs. & $\begin{array}{l}\text { Overall } \\
\text { self-emp. }\end{array}$ & $\begin{array}{l}\text { Incorp. } \\
\text { self-emp. }\end{array}$ \\
\hline Total & $1,324,102$ & 108,070 & 35,970 & BLZ & 1225 & 101 & 26 \\
\hline Employed & 991,662 & 0 & 0 & BMU & 530 & 54 & 10 \\
\hline Self-employed (uninc.) & 72,100 & 72,100 & 0 & BOL & 1611 & 158 & 39 \\
\hline Self-employed (inc.) & 35,970 & 35,970 & 35,970 & BRA & 6318 & 1035 & 249 \\
\hline Unpaid family worker & 4813 & 0 & 0 & $\mathrm{BRB}$ & 1585 & 83 & 15 \\
\hline N/A & 219,557 & 0 & 0 & CHL & 2442 & 353 & 108 \\
\hline Unemployed & 55,279 & 3413 & 907 & $\mathrm{COL}$ & 15,227 & 1794 & 569 \\
\hline Total, remaining, of which: & $1,052,446$ & 104,657 & 35,063 & CRI & 2208 & 208 & 54 \\
\hline Mean age & 39 & 44 & 45 & CUB & 24,559 & 3198 & 1419 \\
\hline Female & 470,862 & 39,135 & 10,317 & DMA & 482 & 23 & 10 \\
\hline Male & 581,584 & 65,522 & 24,746 & DOM & 18,227 & 1517 & 498 \\
\hline Mean no. of children & 1.1 & 1.2 & 1.3 & ECU & 8690 & 757 & 249 \\
\hline Married, spouse present & 624,562 & 73,615 & 26,725 & GRD & 826 & 62 & 23 \\
\hline Married, spouse absent & 57,225 & 4025 & 1135 & GTM & 14,892 & 1321 & 246 \\
\hline Separated & 33,356 & 2906 & 688 & GUY & 6334 & 388 & 155 \\
\hline Divorced & 83,189 & 9018 & 2592 & HND & 8461 & 661 & 168 \\
\hline Widowed & 19,153 & 2115 & 477 & HTI & 12,394 & 600 & 187 \\
\hline Never married/single & 234,961 & 12,978 & 3446 & JAM & 17,008 & 1150 & 344 \\
\hline
\end{tabular}


Table 6 continued

\begin{tabular}{|c|c|c|c|c|c|c|c|}
\hline & Obs. & $\begin{array}{l}\text { Overall } \\
\text { self-emp. }\end{array}$ & $\begin{array}{l}\text { Incorp. } \\
\text { self-emp. }\end{array}$ & & Obs. & $\begin{array}{l}\text { Overall } \\
\text { self-emp. }\end{array}$ & $\begin{array}{l}\text { Incorp. } \\
\text { self-emp. }\end{array}$ \\
\hline Does not speak English & 74,619 & 5124 & 1215 & KNA & 373 & 13 & 2 \\
\hline Speaks only English & 267,991 & 27,800 & 9085 & LCA & 403 & 24 & 8 \\
\hline Speaks very well & 326,486 & 31,780 & 12,491 & MEX & 266,378 & 19,354 & 4685 \\
\hline Speaks well & 212,160 & 23,447 & 7820 & NIC & 6810 & 578 & 174 \\
\hline Speaks not well & 171,190 & 16,506 & 4452 & PAN & 4255 & 261 & 91 \\
\hline No education or preschool & 41,173 & 3842 & 1003 & PER & 8766 & 885 & 254 \\
\hline Grade $1,2,3,4$ & 23,973 & 2101 & 417 & PRI & 34,734 & 1867 & 564 \\
\hline Grade $5,6,7,8$ & 115,638 & 10,272 & 2600 & PRY & 336 & 77 & 21 \\
\hline Grade 9 & 41,591 & 3500 & 889 & SLV & 26,874 & 2351 & 466 \\
\hline Grade 10 & 25,811 & 2488 & 702 & TTO & 5882 & 440 & 128 \\
\hline Grade 11 & 24,965 & 2160 & 579 & URY & 804 & 129 & 53 \\
\hline Grade 12 & 274,020 & 27,669 & 8395 & VCI & 570 & 33 & 9 \\
\hline $1-3$ years of college & 239,829 & 22,930 & 7910 & VEN & 3135 & 350 & 136 \\
\hline $4+$ years of college & 265,446 & 29,695 & 12,568 & VIR & 1432 & 68 & 19 \\
\hline Agriculture & 41,430 & 6685 & 1589 & DZA & 332 & 35 & 15 \\
\hline Construction & 78,963 & 13,976 & 4228 & EGY & 3412 & 463 & 197 \\
\hline Retail & 155,128 & 19,018 & 8019 & IRN & 8952 & 1910 & 816 \\
\hline Services & 111,921 & 21,475 & 6515 & IRQ & 2276 & 398 & 189 \\
\hline Transport & 16,828 & 3994 & 1289 & ISR & 3594 & 806 & 400 \\
\hline Medical & 47,005 & 5643 & 2422 & JOR & 1394 & 284 & 115 \\
\hline Households & 12,797 & 5774 & 0 & KWT & 510 & 48 & 26 \\
\hline Owner of dwelling & 577,576 & 70,207 & 26,074 & $\mathrm{LBN}$ & 3303 & 684 & 323 \\
\hline Immigrant & 969,114 & 96,040 & 32,449 & MAR & 1279 & 144 & 52 \\
\hline EAP & 183,096 & 19,149 & 6936 & SAU & 366 & 34 & 16 \\
\hline EECA & 49,865 & 6248 & 2263 & SYR & 1442 & 348 & 132 \\
\hline LAC & 509,150 & 40,620 & 11,274 & YEM & 423 & 77 & 24 \\
\hline MENA & 27,283 & 5231 & 2305 & CAN & 25,385 & 3489 & 1203 \\
\hline NAM & 25,385 & 3489 & 1203 & ASM & 732 & 39 & 12 \\
\hline OCEA & 7870 & 752 & 235 & AUS & 2180 & 300 & 112 \\
\hline SAS & 42,463 & 4669 & 2314 & FJI & 1013 & 72 & 16 \\
\hline SSA & 17,517 & 1529 & 572 & GUM & 2028 & 112 & 26 \\
\hline WEU & 106,485 & 14,353 & 5347 & NZL & 883 & 138 & 54 \\
\hline $\mathrm{CHN}$ & 27,848 & 2802 & 1184 & TON & 509 & 71 & 11 \\
\hline $\mathrm{HKG}$ & 6910 & 645 & 270 & WSM & 525 & 20 & 4 \\
\hline IDN & 2086 & 187 & 66 & AFG & 1174 & 153 & 47 \\
\hline JPN & 13,637 & 1524 & 487 & BGD & 2275 & 214 & 75 \\
\hline KHM & 3926 & 407 & 112 & IND & 31,866 & 3362 & 1752 \\
\hline KOR & 24,527 & 5390 & 1865 & LKA & 885 & 101 & 41 \\
\hline LAO & 5790 & 284 & 99 & NPL & 355 & 23 & 9 \\
\hline MMR & 1123 & 99 & 47 & PAK & 5908 & 816 & 390 \\
\hline MYS & 1565 & 140 & 70 & CMR & 359 & 22 & 9 \\
\hline PHL & 48,129 & 2510 & 795 & CPV & 787 & 26 & 9 \\
\hline SGP & 658 & 61 & 25 & ERI & 513 & 52 & 13 \\
\hline THA & 4405 & 413 & 139 & ETH & 2156 & 146 & 48 \\
\hline
\end{tabular}


Table 6 continued

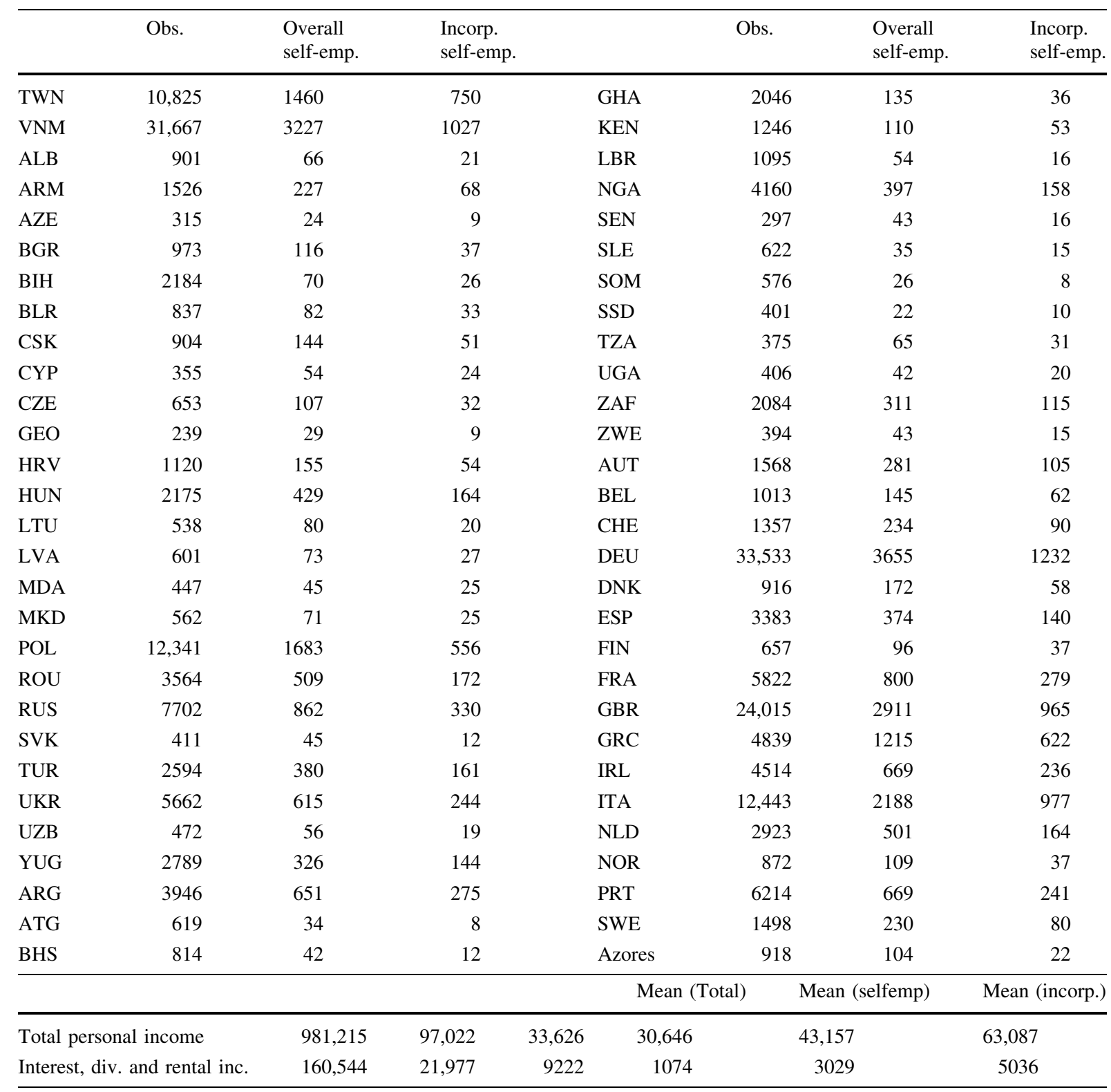


Table 7 Probability of being self-employed by country of origin

\begin{tabular}{|c|c|c|c|c|c|c|c|c|c|}
\hline & $\begin{array}{l}(1) \\
\text { (All) }\end{array}$ & (2) & $\begin{array}{l}(3) \\
\text { (Excl. US) }\end{array}$ & (4) & & $\begin{array}{l}(1) \\
\text { (All) }\end{array}$ & (2) & $\begin{array}{l}(3) \\
\text { (Excl. US) }\end{array}$ & (4) \\
\hline & Overall & Inc & Overall & Inc & & Overall & Inc & Overall & Inc \\
\hline ASM & $\begin{array}{l}-0.060 \\
(0.014)^{* * *}\end{array}$ & $\begin{array}{l}-0.023 \\
(0.010)^{* *}\end{array}$ & $\begin{array}{c}0.033 \\
(0.019)^{*}\end{array}$ & & HRV & $\begin{array}{c}0.005 \\
(0.008)\end{array}$ & $\begin{array}{c}0.004 \\
(0.005)\end{array}$ & $\begin{array}{l}0.098 \\
(0.020)^{* * *}\end{array}$ & $\begin{array}{l}0.061 \\
(0.017)^{* * *}\end{array}$ \\
\hline GUM & $\begin{array}{l}-0.041 \\
(0.008) * * *\end{array}$ & $\begin{array}{l}-0.026 \\
(0.007)^{* * *}\end{array}$ & $\begin{array}{l}0.053 \\
(0.020)^{* * *}\end{array}$ & $\begin{array}{c}0.030 \\
(0.018)^{*}\end{array}$ & $\mathrm{BIH}$ & $\begin{array}{l}-0.088 \\
(0.010)^{* * *}\end{array}$ & $\begin{array}{l}-0.031 \\
(0.006)^{* * *}\end{array}$ & $\begin{array}{c}0.005 \\
(0.021)\end{array}$ & $\begin{array}{c}0.026 \\
(0.018)\end{array}$ \\
\hline PRI & $\begin{array}{l}-0.056 \\
(0.002)^{* * *}\end{array}$ & $\begin{array}{l}-0.024 \\
(0.002)^{* * *}\end{array}$ & $\begin{array}{l}0.037 \\
(0.019)^{* *}\end{array}$ & $\begin{array}{c}0.033 \\
(0.017)^{*}\end{array}$ & LVA & $\begin{array}{r}-0.001 \\
(0.011)\end{array}$ & $\begin{array}{c}0.004 \\
(0.007)\end{array}$ & $\begin{array}{l}0.094 \\
(0.021)^{* * *}\end{array}$ & $\begin{array}{l}0.061 \\
(0.018)^{* * *}\end{array}$ \\
\hline VIR & $\begin{array}{l}-0.046 \\
(0.010)^{* * *}\end{array}$ & $\begin{array}{l}-0.020 \\
(0.008)^{* * *}\end{array}$ & $\begin{array}{l}0.048 \\
(0.021)^{* *}\end{array}$ & $\begin{array}{l}0.037 \\
(0.018)^{* *}\end{array}$ & LTU & $\begin{array}{c}0.013 \\
(0.010)\end{array}$ & $\begin{array}{r}-0.001 \\
(0.008)\end{array}$ & $\begin{array}{l}0.107 \\
(0.021)^{* * *}\end{array}$ & $\begin{array}{l}0.056 \\
(0.018)^{* * *}\end{array}$ \\
\hline CAN & $\begin{array}{l}0.022 \\
(0.002)^{* * *}\end{array}$ & $\begin{array}{l}0.012 \\
(0.001)^{* * *}\end{array}$ & $\begin{array}{l}0.116 \\
(0.019)^{* * *}\end{array}$ & $\begin{array}{l}0.069 \\
(0.017)^{* * *}\end{array}$ & RUS & $\begin{array}{r}-0.001 \\
(0.003)\end{array}$ & $\begin{array}{c}0.004 \\
(0.002)^{*}\end{array}$ & $\begin{array}{l}0.093 \\
(0.019)^{* * *}\end{array}$ & $\begin{array}{l}0.061 \\
(0.017)^{* * *}\end{array}$ \\
\hline BMU & $\begin{array}{r}-0.003 \\
(0.012)\end{array}$ & $\begin{array}{c}-0.018 \\
(0.010)^{*}\end{array}$ & $\begin{array}{l}0.091 \\
(0.022)^{* * *}\end{array}$ & $\begin{array}{c}0.039 \\
(0.020)^{*}\end{array}$ & BLR & $\begin{array}{l}-0.021 \\
(0.010)^{* *}\end{array}$ & $\begin{array}{r}-0.002 \\
(0.006)\end{array}$ & $\begin{array}{l}0.073 \\
(0.021)^{* * *}\end{array}$ & $\begin{array}{l}0.055 \\
(0.018)^{* * *}\end{array}$ \\
\hline $\mathrm{CPV}$ & $\begin{array}{l}-0.086 \\
(0.016)^{* * *}\end{array}$ & $\begin{array}{l}-0.030 \\
(0.011)^{* * *}\end{array}$ & $\begin{array}{c}0.026 \\
(0.020)\end{array}$ & & MDA & $\begin{array}{r}-0.016 \\
(0.013)\end{array}$ & $\begin{array}{c}0.011 \\
(0.007)\end{array}$ & $\begin{array}{l}0.078 \\
(0.023)^{* * *}\end{array}$ & $\begin{array}{l}0.068 \\
(0.018)^{* * *}\end{array}$ \\
\hline MEX & $\begin{array}{l}-0.034 \\
(0.002)^{* * *}\end{array}$ & $\begin{array}{l}-0.017 \\
(0.001)^{* * *}\end{array}$ & $\begin{array}{l}0.060 \\
(0.019)^{* * *}\end{array}$ & $\begin{array}{l}0.039 \\
(0.017)^{* *}\end{array}$ & UKR & $\begin{array}{l}-0.010 \\
(0.004)^{* *}\end{array}$ & $\begin{array}{c}0.003 \\
(0.002)\end{array}$ & $\begin{array}{l}0.084 \\
(0.019)^{* * *}\end{array}$ & $\begin{array}{l}0.060 \\
(0.017)^{* * *}\end{array}$ \\
\hline BLZ & $\begin{array}{l}-0.037 \\
(0.009) * * *\end{array}$ & $\begin{array}{c}-0.012 \\
(0.007)^{*}\end{array}$ & $\begin{array}{l}0.057 \\
(0.021)^{* * *}\end{array}$ & $\begin{array}{l}0.045 \\
(0.018)^{* *}\end{array}$ & ARM & $\begin{array}{l}0.031 \\
(0.007)^{* * *}\end{array}$ & $\begin{array}{l}0.009 \\
(0.004)^{* *}\end{array}$ & $\begin{array}{l}0.124 \\
(0.020)^{* * *}\end{array}$ & $\begin{array}{l}0.065 \\
(0.017)^{* * *}\end{array}$ \\
\hline CRI & $\begin{array}{l}-0.006 \\
(0.006)^{* * *}\end{array}$ & $\begin{array}{l}-0.010 \\
(0.005)^{* *}\end{array}$ & $\begin{array}{l}0.077 \\
(0.020)^{* * *}\end{array}$ & $\begin{array}{l}0.046 \\
(0.017)^{* * *}\end{array}$ & AZE & $\begin{array}{l}-0.043 \\
(0.018)^{* *}\end{array}$ & $\begin{array}{r}-0.012 \\
(0.011)\end{array}$ & $\begin{array}{c}0.051 \\
(0.026)^{* *}\end{array}$ & $\begin{array}{l}0.045 \\
(0.020)^{* *}\end{array}$ \\
\hline SLV & $\begin{array}{l}-0.025 \\
(0.002)^{* * *}\end{array}$ & $\begin{array}{l}-0.015 \\
(0.002)^{* * *}\end{array}$ & $\begin{array}{l}0.069 \\
(0.019)^{* * *}\end{array}$ & $\begin{array}{l}0.042 \\
(0.017)^{* *}\end{array}$ & GEO & $\begin{array}{c}0.012 \\
(0.016)\end{array}$ & $\begin{array}{c}0.002 \\
(0.011)\end{array}$ & $\begin{array}{l}0.105 \\
(0.025)^{* * *}\end{array}$ & $\begin{array}{l}0.059 \\
(0.020)^{* * *}\end{array}$ \\
\hline GTM & $\begin{array}{l}-0.021 \\
(0.003)^{* * *}\end{array}$ & $\begin{array}{l}-0.015 \\
(0.002)^{* * *}\end{array}$ & $\begin{array}{l}0.073 \\
(0.019)^{* * *}\end{array}$ & $\begin{array}{l}0.042 \\
(0.017)^{* *}\end{array}$ & UZB & $\begin{array}{c}0.007 \\
(0.012)\end{array}$ & $\begin{array}{c}0.004 \\
(0.008)\end{array}$ & $\begin{array}{l}0.101 \\
(0.022)^{* * *}\end{array}$ & $\begin{array}{l}0.061 \\
(0.018)^{* * *}\end{array}$ \\
\hline HND & $\begin{array}{l}-0.030 \\
(0.004)^{* * *}\end{array}$ & $\begin{array}{l}-0.010 \\
(0.003)^{* * *}\end{array}$ & $\begin{array}{l}0.064 \\
(0.019)^{* * *}\end{array}$ & $\begin{array}{l}0.047 \\
(0.017)^{* * *}\end{array}$ & $\mathrm{CHN}$ & $\begin{array}{c}0.001 \\
(0.002)\end{array}$ & $\begin{array}{l}0.007 \\
(0.001)^{* * *}\end{array}$ & $\begin{array}{l}0.095 \\
(0.019)^{* * *}\end{array}$ & $\begin{array}{l}0.064 \\
(0.017)^{* * *}\end{array}$ \\
\hline NIC & $\begin{array}{l}-0.030 \\
(0.004)^{* * *}\end{array}$ & $\begin{array}{l}-0.008 \\
(0.003)^{* * *}\end{array}$ & $\begin{array}{l}0.064 \\
(0.019)^{* * *}\end{array}$ & $\begin{array}{l}0.048 \\
(0.017)^{* * *}\end{array}$ & HKG & $\begin{array}{c}0.003 \\
(0.004)\end{array}$ & $\begin{array}{l}0.006 \\
(0.002)^{* * *}\end{array}$ & $\begin{array}{l}0.096 \\
(0.019)^{* * *}\end{array}$ & $\begin{array}{l}0.063 \\
(0.017)^{* * *}\end{array}$ \\
\hline PAN & $\begin{array}{l}-0.043 \\
(0.005)^{* * *}\end{array}$ & $\begin{array}{l}-0.015 \\
(0.004)^{* * *}\end{array}$ & $\begin{array}{l}0.050 \\
(0.019)^{* * *}\end{array}$ & $\begin{array}{l}0.042 \\
(0.017)^{* *}\end{array}$ & TWN & $\begin{array}{c}0.033 \\
(0.003)^{* * *}\end{array}$ & $\begin{array}{l}0.026 \\
(0.002)^{* * *}\end{array}$ & $\begin{array}{l}0.127 \\
(0.019)^{* * *}\end{array}$ & $\begin{array}{l}0.083 \\
(0.017)^{* * *}\end{array}$ \\
\hline CUB & $\begin{array}{l}0.006 \\
(0.002)^{* * *}\end{array}$ & $\begin{array}{l}0.014 \\
(0.001)^{* * *}\end{array}$ & $\begin{array}{l}0.099 \\
(0.019)^{* * *}\end{array}$ & $\begin{array}{l}0.071 \\
(0.017)^{* * *}\end{array}$ & JPN & $\begin{array}{c}0.010 \\
(0.002)^{* * *}\end{array}$ & $\begin{array}{l}0.004 \\
(0.002)^{* *}\end{array}$ & $\begin{array}{l}0.104 \\
(0.019)^{* * *}\end{array}$ & $\begin{array}{l}0.060 \\
(0.017)^{* * *}\end{array}$ \\
\hline DOM & $\begin{array}{l}-0.015 \\
(0.003) * * *\end{array}$ & $\begin{array}{r}-0.002 \\
(0.002)\end{array}$ & $\begin{array}{l}0.078 \\
(0.019)^{* * *}\end{array}$ & $\begin{array}{l}0.054 \\
(0.017)^{* * *}\end{array}$ & KOR & $\begin{array}{c}0.066 \\
(0.002)^{* * *}\end{array}$ & $\begin{array}{l}0.029 \\
(0.001)^{* * *}\end{array}$ & $\begin{array}{l}0.160 \\
(0.019)^{* * *}\end{array}$ & $\begin{array}{l}0.086 \\
(0.017)^{* * *}\end{array}$ \\
\hline HTI & $\begin{array}{l}-0.075 \\
(0.004) * * *\end{array}$ & $\begin{array}{l}-0.030 \\
(0.003)^{* * *}\end{array}$ & $\begin{array}{c}0.018 \\
(0.019)\end{array}$ & $\begin{array}{c}0.026 \\
(0.017)\end{array}$ & KHM & $\begin{array}{l}0.020 \\
(0.004)^{* * *}\end{array}$ & $\begin{array}{c}0.004 \\
(0.003)\end{array}$ & $\begin{array}{l}0.113 \\
(0.019)^{* * *}\end{array}$ & $\begin{array}{l}0.060 \\
(0.017)^{* * *}\end{array}$ \\
\hline JAM & $\begin{array}{l}-0.044 \\
(0.003) * * *\end{array}$ & $\begin{array}{l}-0.015 \\
(0.002)^{* * *}\end{array}$ & $\begin{array}{l}0.050 \\
(0.019)^{* * *}\end{array}$ & $\begin{array}{l}0.042 \\
(0.017)^{* *}\end{array}$ & IDN & $\begin{array}{r}-0.010 \\
(0.007)\end{array}$ & $\begin{array}{r}-0.003 \\
(0.004)\end{array}$ & $\begin{array}{l}0.084 \\
(0.020)^{* * *}\end{array}$ & $\begin{array}{l}0.054 \\
(0.017)^{* * *}\end{array}$ \\
\hline ATG & $\begin{array}{l}-0.058 \\
(0.015) * * *\end{array}$ & $\begin{array}{l}-0.028 \\
(0.012)^{* *}\end{array}$ & $\begin{array}{c}0.036 \\
(0.024)\end{array}$ & $\begin{array}{c}0.029 \\
(0.020)\end{array}$ & LAO & $\begin{array}{l}-0.037 \\
(0.005)^{* * *}\end{array}$ & $\begin{array}{l}-0.012 \\
(0.003)^{* * *}\end{array}$ & $\begin{array}{l}0.056 \\
(0.019)^{* * *}\end{array}$ & $\begin{array}{l}0.044 \\
(0.017)^{* * *}\end{array}$ \\
\hline BHS & $\begin{array}{l}-0.050 \\
(0.013) * * *\end{array}$ & $\begin{array}{l}-0.019 \\
(0.010)^{* *}\end{array}$ & $\begin{array}{c}0.044 \\
(0.023)^{*}\end{array}$ & $\begin{array}{c}0.037 \\
(0.019)^{*}\end{array}$ & MYS & $\begin{array}{c}0.001 \\
(0.007)\end{array}$ & $\begin{array}{l}0.013 \\
(0.004)^{* * *}\end{array}$ & $\begin{array}{l}0.095 \\
(0.020)^{* * *}\end{array}$ & $\begin{array}{l}0.070 \\
(0.017)^{* * *}\end{array}$ \\
\hline BRB & $\begin{array}{l}-0.074 \\
(0.010)^{* * *}\end{array}$ & $\begin{array}{l}-0.039 \\
(0.009)^{* * *}\end{array}$ & $\begin{array}{c}0.020 \\
(0.021)\end{array}$ & $\begin{array}{c}0.017 \\
(0.019)\end{array}$ & PHL & $\begin{array}{l}-0.063 \\
(0.002)^{* * *}\end{array}$ & $\begin{array}{l}-0.027 \\
(0.001)^{* * *}\end{array}$ & $\begin{array}{c}0.031 \\
(0.019)^{*}\end{array}$ & $\begin{array}{c}0.030 \\
(0.017)^{*}\end{array}$ \\
\hline DMA & $\begin{array}{l}-0.076 \\
(0.018)^{* * *}\end{array}$ & $\begin{array}{r}-0.015 \\
(0.011)\end{array}$ & $\begin{array}{c}0.017 \\
(0.026)\end{array}$ & $\begin{array}{c}0.041 \\
(0.020)^{* *}\end{array}$ & SGP & $\begin{array}{c}0.013 \\
(0.011)\end{array}$ & $\begin{array}{c}0.011 \\
(0.007)\end{array}$ & $\begin{array}{l}0.107 \\
(0.022) * * *\end{array}$ & $\begin{array}{l}0.068 \\
(0.018)^{* * * *}\end{array}$ \\
\hline
\end{tabular}


Table 7 continued

\begin{tabular}{|c|c|c|c|c|c|c|c|c|c|}
\hline & $\begin{array}{l}\text { (1) } \\
\text { (All) }\end{array}$ & (2) & $\begin{array}{l}(3) \\
\text { (Excl. US) }\end{array}$ & (4) & & $\begin{array}{l}\text { (1) } \\
\text { (All) }\end{array}$ & (2) & $\begin{array}{l}(3) \\
\text { (Excl. US) }\end{array}$ & (4) \\
\hline & Overall & Inc & Overall & Inc & & Overall & Inc & Overall & Inc \\
\hline GRD & $\begin{array}{l}-0.050 \\
(0.011)^{* * *}\end{array}$ & $\begin{array}{r}-0.007 \\
(0.007)\end{array}$ & $\begin{array}{l}0.044 \\
(0.022)^{* *}\end{array}$ & $\begin{array}{l}0.050 \\
(0.018)^{* * *}\end{array}$ & THA & $\begin{array}{c}0.002 \\
(0.004)\end{array}$ & $\begin{array}{c}0.002 \\
(0.003)\end{array}$ & $\begin{array}{l}0.095 \\
(0.019)^{* * *}\end{array}$ & $\begin{array}{l}0.059 \\
(0.017)^{* * *}\end{array}$ \\
\hline KNA & $\begin{array}{l}-0.101 \\
(0.023)^{* * *}\end{array}$ & $\begin{array}{l}-0.058 \\
(0.023)^{* *}\end{array}$ & $\begin{array}{r}-0.002 \\
(0.029)\end{array}$ & & VNM & $\begin{array}{l}0.013 \\
(0.002)^{* * *}\end{array}$ & $\begin{array}{l}0.006 \\
(0.001)^{* * *}\end{array}$ & $\begin{array}{l}0.106 \\
(0.019)^{* * *}\end{array}$ & $\begin{array}{l}0.063 \\
(0.017)^{* * *}\end{array}$ \\
\hline LCA & $\begin{array}{l}-0.062 \\
(0.018)^{* * *}\end{array}$ & $\begin{array}{c}-0.017 \\
(0.012)\end{array}$ & $\begin{array}{c}0.032 \\
(0.026)\end{array}$ & $\begin{array}{c}0.039 \\
(0.020)^{*}\end{array}$ & AFG & $\begin{array}{c}0.010 \\
(0.007)\end{array}$ & $\begin{array}{r}-0.002 \\
(0.005)\end{array}$ & $\begin{array}{l}0.103 \\
(0.020)^{* * *}\end{array}$ & $\begin{array}{l}0.054 \\
(0.017)^{* * *}\end{array}$ \\
\hline $\mathrm{VCI}$ & $\begin{array}{l}-0.066 \\
(0.016)^{* * *}\end{array}$ & $\begin{array}{l}-0.025 \\
(0.011)^{* *}\end{array}$ & $\begin{array}{c}0.027 \\
(0.024)\end{array}$ & $\begin{array}{c}0.031 \\
(0.020)\end{array}$ & IND & $\begin{array}{l}0.008 \\
(0.002)^{* * *}\end{array}$ & $\begin{array}{l}0.013 \\
(0.001)^{* * *}\end{array}$ & $\begin{array}{l}0.102 \\
(0.019)^{* * *}\end{array}$ & $\begin{array}{l}0.070 \\
(0.017)^{* * *}\end{array}$ \\
\hline TTO & $\begin{array}{l}-0.037 \\
(0.004)^{* * *}\end{array}$ & $\begin{array}{l}-0.013 \\
(0.003)^{* * *}\end{array}$ & $\begin{array}{l}0.057 \\
(0.019)^{* * *}\end{array}$ & $\begin{array}{l}0.044 \\
(0.017)^{* * * *}\end{array}$ & BGD & $\begin{array}{l}-0.018 \\
(0.006)^{* * *}\end{array}$ & $\begin{array}{l}-0.011 \\
(0.004)^{* * *}\end{array}$ & $\begin{array}{l}0.075 \\
(0.020)^{* * *}\end{array}$ & $\begin{array}{l}0.046 \\
(0.017)^{* * *}\end{array}$ \\
\hline ARG & $\begin{array}{l}0.029 \\
(0.004)^{* * *}\end{array}$ & $\begin{array}{l}0.021 \\
(0.002)^{* * *}\end{array}$ & $\begin{array}{l}0.123 \\
(0.019)^{* * *}\end{array}$ & $\begin{array}{l}0.078 \\
(0.017)^{* * *}\end{array}$ & MMR & $\begin{array}{r}-0.013 \\
(0.009)\end{array}$ & $\begin{array}{c}0.003 \\
(0.005)\end{array}$ & $\begin{array}{l}0.080 \\
(0.021)^{* * *}\end{array}$ & $\begin{array}{l}0.060 \\
(0.017)^{* * *}\end{array}$ \\
\hline BOL & $\begin{array}{l}-0.027 \\
(0.007)^{* * *}\end{array}$ & $\begin{array}{l}-0.015 \\
(0.005)^{* * *}\end{array}$ & $\begin{array}{l}0.067 \\
(0.020)^{* * *}\end{array}$ & $\begin{array}{l}0.042 \\
(0.018)^{* *}\end{array}$ & PAK & $\begin{array}{l}0.011 \\
(0.003)^{* * *}\end{array}$ & $\begin{array}{l}0.011 \\
(0.002)^{* * *}\end{array}$ & $\begin{array}{l}0.105 \\
(0.019)^{* * *}\end{array}$ & $\begin{array}{l}0.068 \\
(0.017)^{* * *}\end{array}$ \\
\hline BRA & $\begin{array}{l}0.028 \\
(0.003) * * *\end{array}$ & $\begin{array}{l}0.009 \\
(0.002)^{* * *}\end{array}$ & $\begin{array}{l}0.121 \\
(0.019)^{* * *}\end{array}$ & $\begin{array}{l}0.066 \\
(0.017)^{* * *}\end{array}$ & LKA & $\begin{array}{c}0.006 \\
(0.009)\end{array}$ & $\begin{array}{c}0.007 \\
(0.005)\end{array}$ & $\begin{array}{l}0.100 \\
(0.021)^{* * *}\end{array}$ & $\begin{array}{l}0.064 \\
(0.017)^{* * *}\end{array}$ \\
\hline CHL & $\begin{array}{l}0.010 \\
(0.005)^{* *}\end{array}$ & $\begin{array}{c}0.005 \\
(0.003)\end{array}$ & $\begin{array}{l}0.104 \\
(0.019)^{* * *}\end{array}$ & $\begin{array}{l}0.061 \\
(0.017)^{* * * *}\end{array}$ & IRN & $\begin{array}{l}0.053 \\
(0.003)^{* * *}\end{array}$ & $\begin{array}{l}0.026 \\
(0.002)^{* * *}\end{array}$ & $\begin{array}{l}0.147 \\
(0.019)^{* * *}\end{array}$ & $\begin{array}{l}0.083 \\
(0.017)^{* * *}\end{array}$ \\
\hline $\mathrm{COL}$ & $\begin{array}{c}0.001 \\
(0.003)\end{array}$ & $\begin{array}{l}0.005 \\
(0.002)^{* * *}\end{array}$ & $\begin{array}{l}0.094 \\
(0.019)^{* * *}\end{array}$ & $\begin{array}{l}0.061 \\
(0.017)^{* * *}\end{array}$ & NPL & $\begin{array}{l}-0.032 \\
(0.018)^{*}\end{array}$ & $\begin{array}{r}-0.006 \\
(0.011)\end{array}$ & $\begin{array}{l}0.062 \\
(0.026)^{* *}\end{array}$ & $\begin{array}{c}0.050 \\
(0.020)^{* *}\end{array}$ \\
\hline ECU & $\begin{array}{l}-0.019 \\
(0.003)^{* * *}\end{array}$ & $\begin{array}{r}-0.003 \\
(0.002)\end{array}$ & $\begin{array}{l}0.074 \\
(0.019)^{* * *}\end{array}$ & $\begin{array}{l}0.053 \\
(0.017)^{* * *}\end{array}$ & CYP & $\begin{array}{c}0.021 \\
(0.012)^{*}\end{array}$ & $\begin{array}{l}0.016 \\
(0.007)^{* *}\end{array}$ & $\begin{array}{l}0.073 \\
(0.018)^{* * *}\end{array}$ & \\
\hline GUY & $\begin{array}{l}-0.050 \\
(0.004)^{* * *}\end{array}$ & $\begin{array}{l}-0.011 \\
(0.003)^{* * *}\end{array}$ & $\begin{array}{c}0.043 \\
(0.019)^{* *}\end{array}$ & $\begin{array}{l}0.046 \\
(0.017)^{* * *}\end{array}$ & IRQ & $\begin{array}{l}0.042 \\
(0.005)^{* * *}\end{array}$ & $\begin{array}{l}0.028 \\
(0.003)^{* * *}\end{array}$ & $\begin{array}{l}0.135 \\
(0.019)^{* * *}\end{array}$ & $\begin{array}{l}0.084 \\
(0.017)^{* * *}\end{array}$ \\
\hline PRY & $\begin{array}{l}0.037 \\
(0.012) * * *\end{array}$ & $\begin{array}{l}0.022 \\
(0.008)^{* * *}\end{array}$ & $\begin{array}{l}0.131 \\
(0.022)^{* * *}\end{array}$ & $\begin{array}{l}0.079 \\
(0.018)^{* * *}\end{array}$ & ISR & $\begin{array}{l}0.066 \\
(0.004)^{* * * *}\end{array}$ & $\begin{array}{l}0.037 \\
(0.002)^{* * *}\end{array}$ & $\begin{array}{l}0.160 \\
(0.019)^{* * *}\end{array}$ & $\begin{array}{l}0.094 \\
(0.017)^{* * *}\end{array}$ \\
\hline PER & $\begin{array}{l}-0.017 \\
(0.003)^{* * *}\end{array}$ & $\begin{array}{l}-0.007 \\
(0.002)^{* * *}\end{array}$ & $\begin{array}{l}0.077 \\
(0.019)^{* * *}\end{array}$ & $\begin{array}{l}0.050 \\
(0.017)^{* * *}\end{array}$ & JOR & $\begin{array}{l}0.050 \\
(0.006)^{* * *}\end{array}$ & $\begin{array}{l}0.021 \\
(0.003)^{* * *}\end{array}$ & $\begin{array}{l}0.143 \\
(0.020)^{* * *}\end{array}$ & $\begin{array}{l}0.078 \\
(0.017)^{* * *}\end{array}$ \\
\hline URY & $\begin{array}{l}0.026 \\
(0.008) * * *\end{array}$ & $\begin{array}{l}0.020 \\
(0.005)^{* * *}\end{array}$ & $\begin{array}{l}0.119 \\
(0.020)^{* * *}\end{array}$ & $\begin{array}{l}0.077 \\
(0.017)^{* * * *}\end{array}$ & KWT & $\begin{array}{c}0.004 \\
(0.013)\end{array}$ & $\begin{array}{c}0.013 \\
(0.007)^{*}\end{array}$ & $\begin{array}{l}0.098 \\
(0.023)^{* * *}\end{array}$ & $\begin{array}{l}0.070 \\
(0.018)^{* * *}\end{array}$ \\
\hline VEN & $\begin{array}{c}0.009 \\
(0.005)^{*}\end{array}$ & $\begin{array}{l}0.010 \\
(0.003)^{* * *}\end{array}$ & $\begin{array}{l}0.103 \\
(0.019)^{* * *}\end{array}$ & $\begin{array}{l}0.067 \\
(0.017)^{* * *}\end{array}$ & LBN & $\begin{array}{l}0.058 \\
(0.004)^{* * *}\end{array}$ & $\begin{array}{l}0.031 \\
(0.002)^{* * *}\end{array}$ & $\begin{array}{l}0.151 \\
(0.019)^{* * *}\end{array}$ & $\begin{array}{l}0.088 \\
(0.017)^{* * *}\end{array}$ \\
\hline DNK & $\begin{array}{l}0.048 \\
(0.007)^{* * *}\end{array}$ & $\begin{array}{l}0.021 \\
(0.005)^{* * *}\end{array}$ & $\begin{array}{l}0.142 \\
(0.020)^{* * *}\end{array}$ & $\begin{array}{l}0.077 \\
(0.017)^{* * * *}\end{array}$ & SAU & $\begin{array}{c}0.012 \\
(0.015)\end{array}$ & $\begin{array}{c}0.013 \\
(0.009)\end{array}$ & $\begin{array}{l}0.105 \\
(0.024)^{* * *}\end{array}$ & $\begin{array}{l}0.070 \\
(0.019)^{* * *}\end{array}$ \\
\hline FIN & $\begin{array}{l}0.024 \\
(0.010)^{* *}\end{array}$ & $\begin{array}{l}0.017 \\
(0.006)^{* * *}\end{array}$ & $\begin{array}{l}0.118 \\
(0.021)^{* * *}\end{array}$ & $\begin{array}{l}0.074 \\
(0.018)^{* * *}\end{array}$ & SYR & $\begin{array}{l}0.064 \\
(0.005)^{* * *}\end{array}$ & $\begin{array}{l}0.026 \\
(0.003)^{* * *}\end{array}$ & $\begin{array}{l}0.157 \\
(0.019)^{* * *}\end{array}$ & $\begin{array}{l}0.083 \\
(0.017)^{* * *}\end{array}$ \\
\hline NOR & $\begin{array}{c}0.009 \\
(0.009)\end{array}$ & $\begin{array}{c}0.004 \\
(0.006)\end{array}$ & $\begin{array}{l}0.103 \\
(0.021)^{* * *}\end{array}$ & $\begin{array}{l}0.061 \\
(0.018)^{* * *}\end{array}$ & TUR & $\begin{array}{l}0.036 \\
(0.005)^{* * *}\end{array}$ & $\begin{array}{l}0.021 \\
(0.003)^{* * *}\end{array}$ & $\begin{array}{l}0.129 \\
(0.019)^{* * *}\end{array}$ & $\begin{array}{l}0.078 \\
(0.017)^{* * *}\end{array}$ \\
\hline SWE & $\begin{array}{l}0.036 \\
(0.006)^{* * * *}\end{array}$ & $\begin{array}{l}0.016 \\
(0.004)^{* * *}\end{array}$ & $\begin{array}{l}0.130 \\
(0.020)^{* * *}\end{array}$ & $\begin{array}{l}0.073 \\
(0.017)^{* * *}\end{array}$ & YEM & $\begin{array}{l}0.059 \\
(0.010)^{* * *}\end{array}$ & $\begin{array}{l}0.020 \\
(0.007)^{* * *}\end{array}$ & $\begin{array}{l}0.152 \\
(0.021)^{* * *}\end{array}$ & $\begin{array}{l}0.077 \\
(0.018)^{* * *}\end{array}$ \\
\hline GBR & $\begin{array}{l}0.011 \\
(0.002)^{* * *}\end{array}$ & $\begin{array}{l}0.006 \\
(0.001)^{* * *}\end{array}$ & $\begin{array}{l}0.105 \\
(0.019)^{* * *}\end{array}$ & $\begin{array}{l}0.063 \\
(0.017)^{* * * *}\end{array}$ & DZA & $\begin{array}{r}-0.009 \\
(0.015)\end{array}$ & $\begin{array}{c}0.001 \\
(0.009)\end{array}$ & $\begin{array}{l}0.084 \\
(0.024)^{* * *}\end{array}$ & $\begin{array}{l}0.058 \\
(0.019)^{* * *}\end{array}$ \\
\hline IRL & $\begin{array}{l}0.018 \\
(0.004)^{* * * *}\end{array}$ & $\begin{array}{l}0.013 \\
(0.002)^{* * *}\end{array}$ & $\begin{array}{l}0.112 \\
(0.019)^{* * *}\end{array}$ & $\begin{array}{l}0.070 \\
(0.017)^{* * *}\end{array}$ & EGY & $\begin{array}{c}0.007 \\
(0.004)\end{array}$ & $\begin{array}{l}0.006 \\
(0.003)^{* *}\end{array}$ & $\begin{array}{l}0.101 \\
(0.019)^{* * *}\end{array}$ & $\begin{array}{l}0.063 \\
(0.017)^{* * *}\end{array}$ \\
\hline BEL & $\begin{array}{l}0.027 \\
(0.008)^{* * * *}\end{array}$ & $\begin{array}{l}0.018 \\
(0.004)^{* * *}\end{array}$ & $\begin{array}{l}0.121 \\
(0.020)^{* * *}\end{array}$ & $\begin{array}{l}0.075 \\
(0.017)^{* * *}\end{array}$ & MAR & $\begin{array}{c}0.002 \\
(0.007)\end{array}$ & $\begin{array}{c}0.001 \\
(0.005)\end{array}$ & $\begin{array}{l}0.095 \\
(0.020)^{* * *}\end{array}$ & $\begin{array}{l}0.058 \\
(0.017)^{* * *}\end{array}$ \\
\hline FRA & 0.025 & 0.012 & 0.119 & 0.069 & SSD & -0.055 & -0.016 & 0.038 & 0.041 \\
\hline
\end{tabular}


Table 7 continued

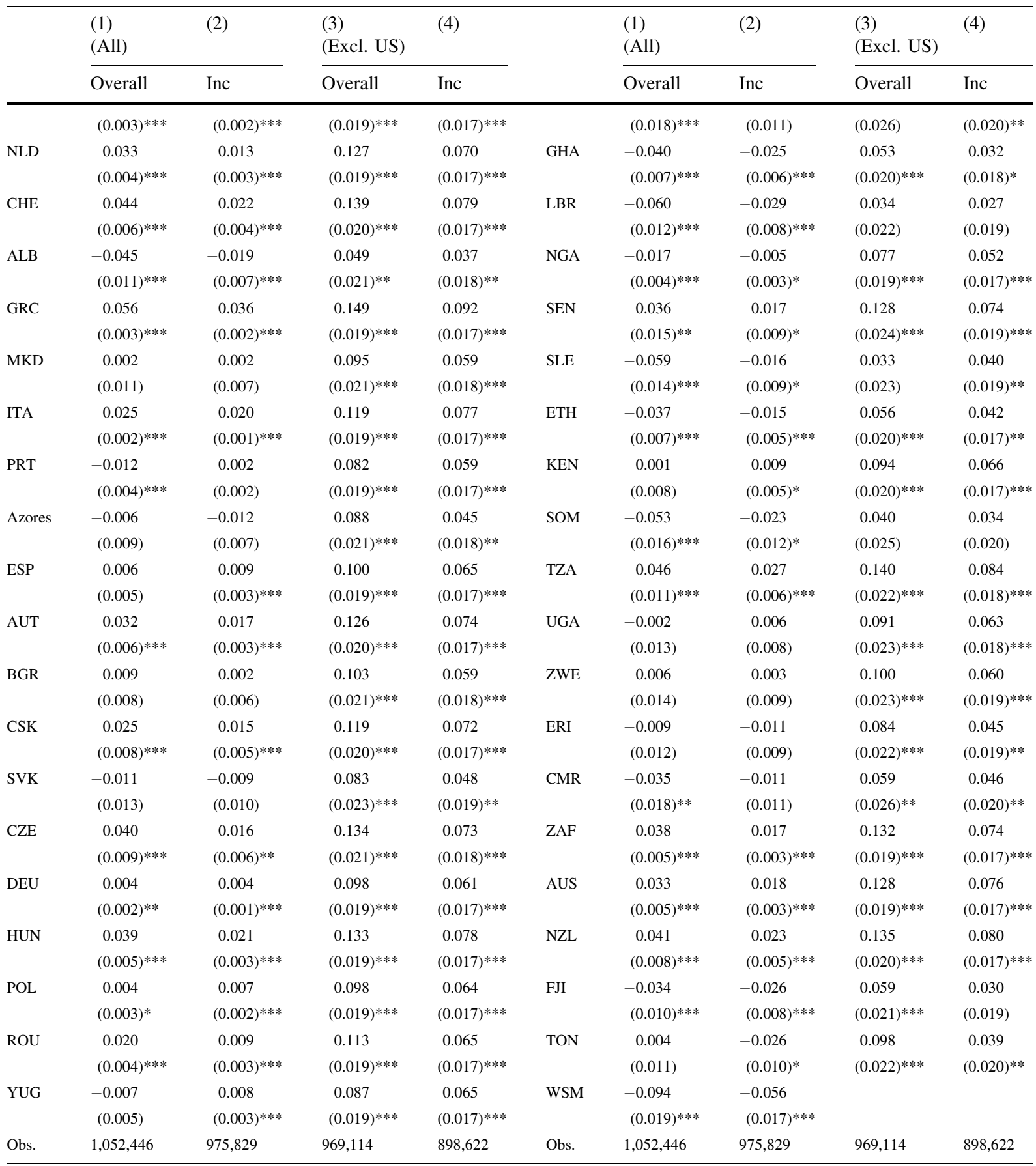

Marginal effects from logit regressions for the year 2000 calculated with robust standard errors. The dependent variable is a dummy for being self-employed, where Overall includes the unincorporated and the incorporated self-employed; Inc includes the incorporated self-employed. The estimations included the following variables not shown in the Table above: age, age squared, a dummy for being male, number of children, dummies for marital status, education, proficiency in english and industry of employment *** Significant on the $1 \%$-level, ** significant on the $5 \%$-level, * significant on the $10 \%$-level 


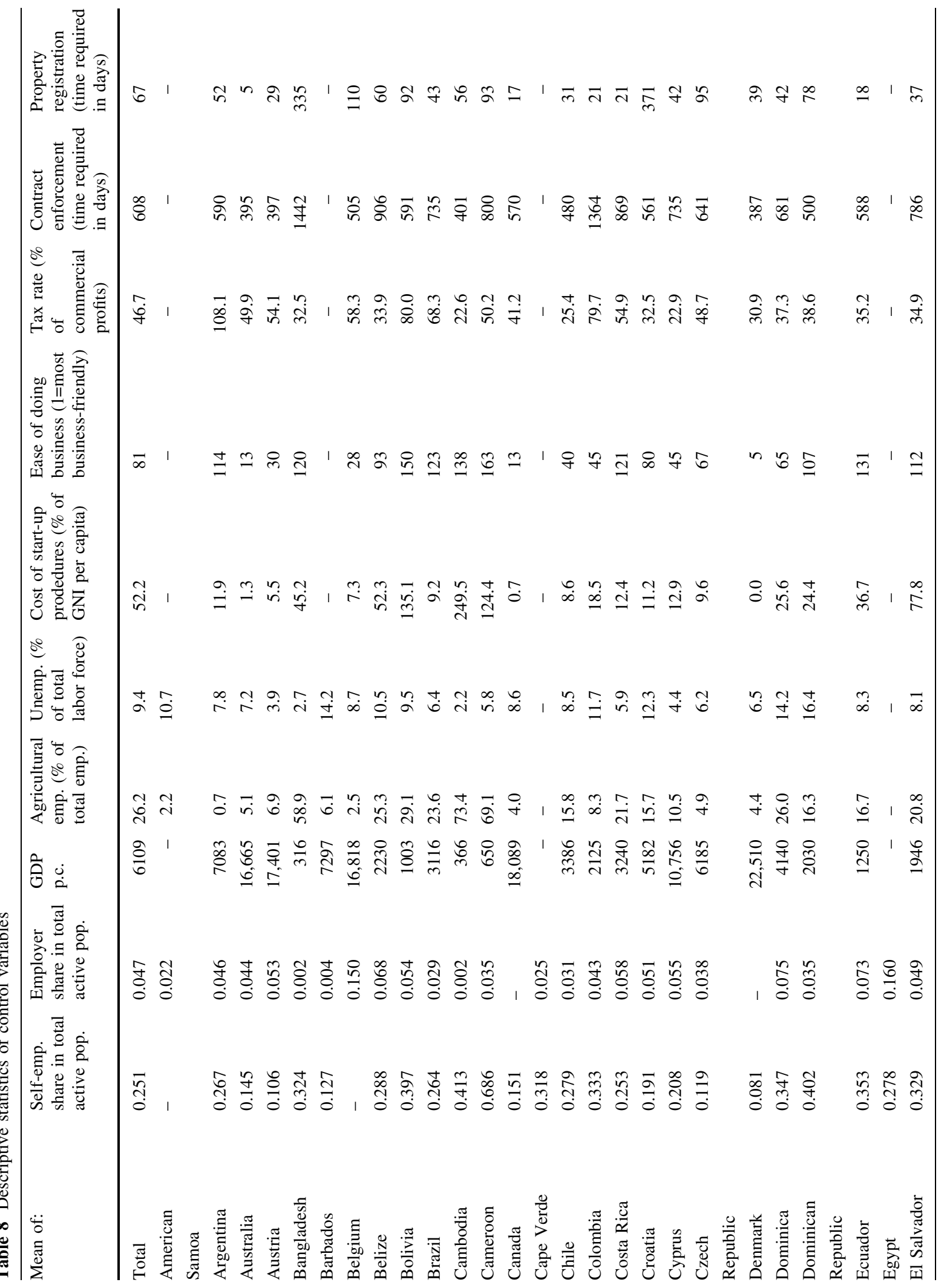




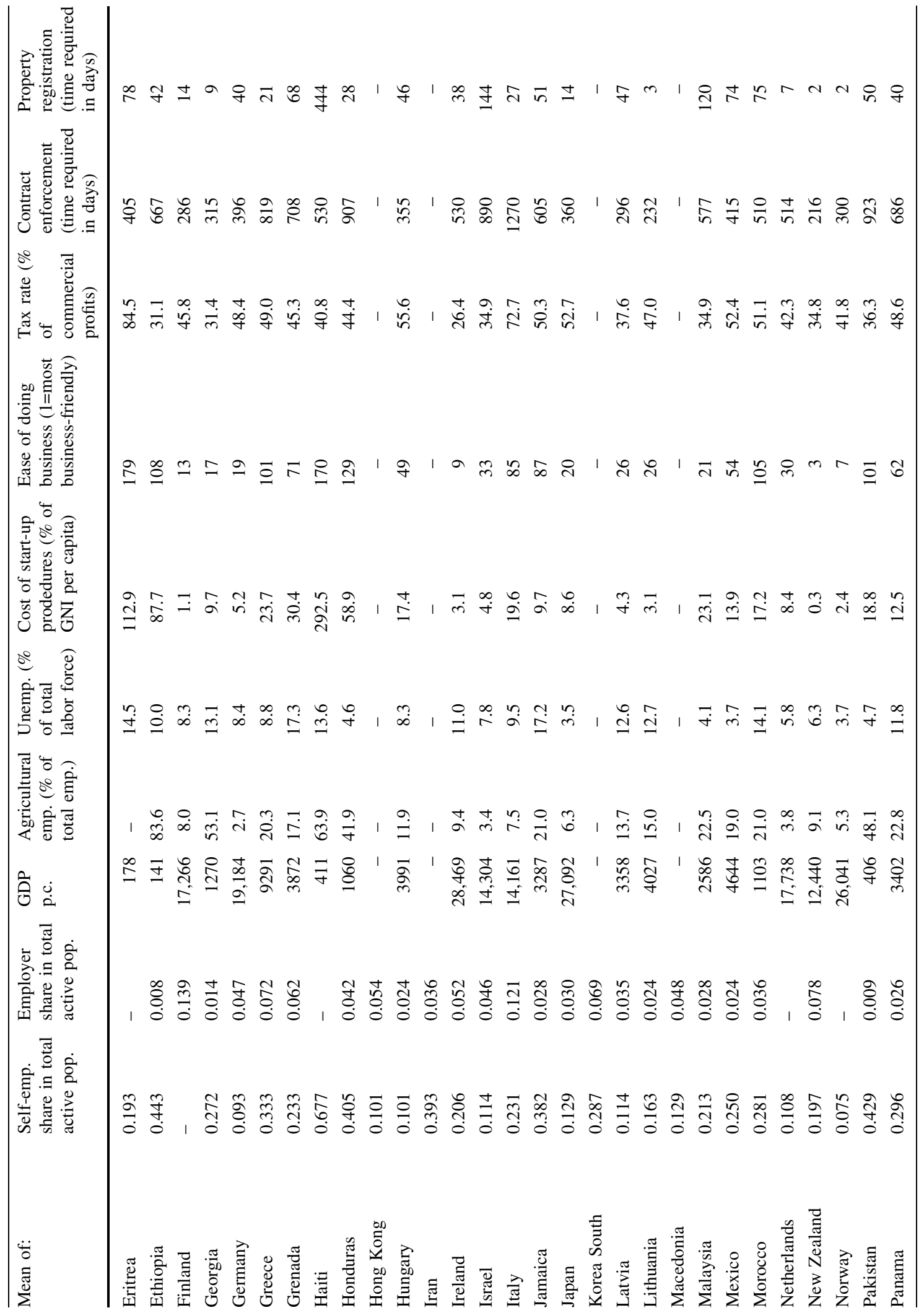




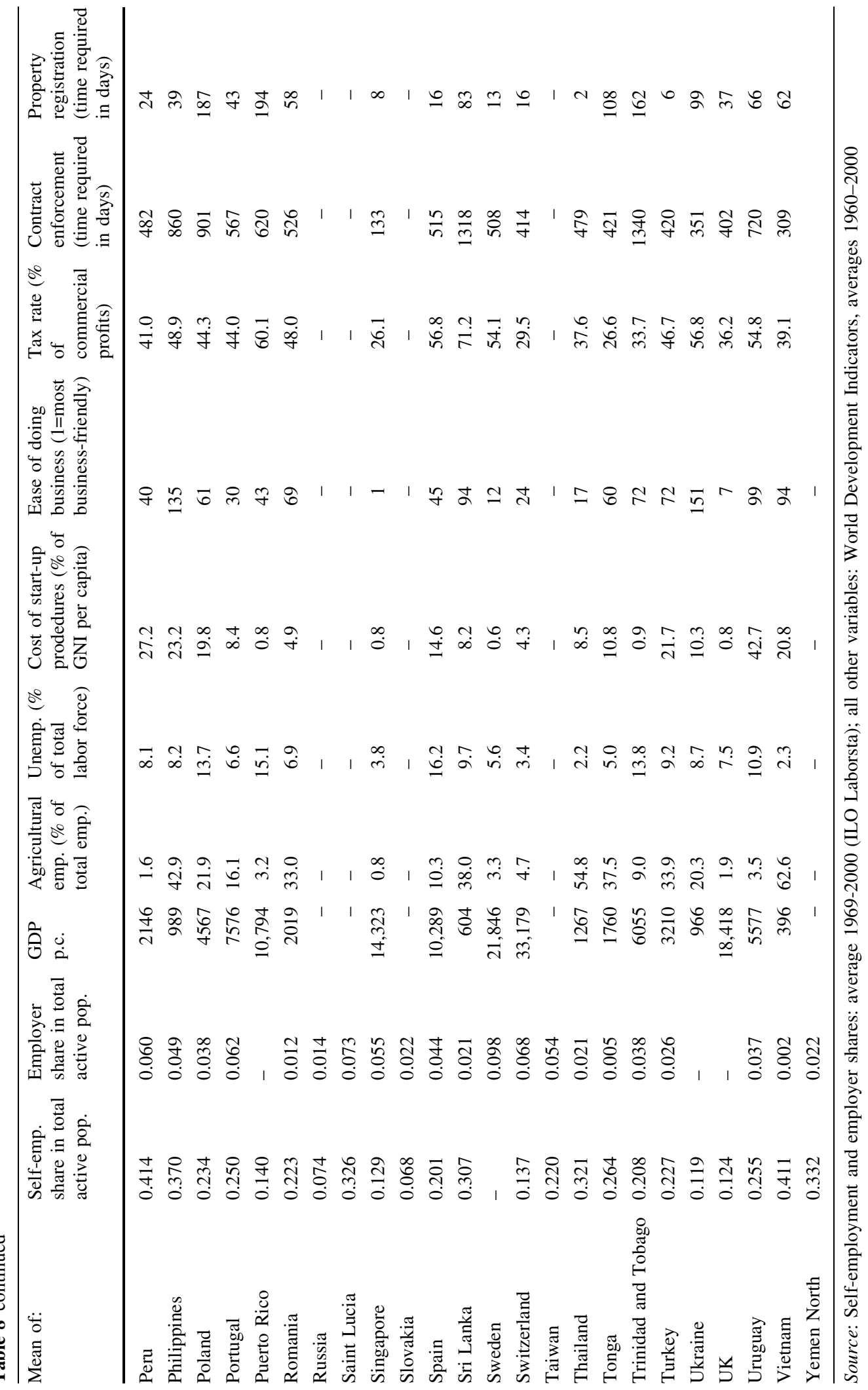


Table 9 Descriptive statistics of control variables (descendants of immigrants)

\begin{tabular}{|c|c|c|c|c|c|c|c|}
\hline Mean of: & $\begin{array}{l}\text { Self-emp. share } \\
\text { in total active } \\
\text { pop. }\end{array}$ & $\begin{array}{l}\text { Employer share } \\
\text { in total active } \\
\text { pop. }\end{array}$ & $\begin{array}{l}\text { GDP } \\
\text { p.c. }\end{array}$ & & $\begin{array}{l}\text { Self-emp. share } \\
\text { in total active } \\
\text { pop. }\end{array}$ & $\begin{array}{l}\text { Employer share } \\
\text { in total active } \\
\text { pop. }\end{array}$ & GDP p.c. \\
\hline Total & 0.188 & 0.028 & 7660 & India & 0.100 & 0.011 & 190 \\
\hline Albania & 0.223 & - & - & Israel & 0.178 & 0.025 & 6776.479 \\
\hline American Samoa & 0.203 & - & - & Italy & 0.261 & - & 6676.396 \\
\hline Argentina & 0.233 & 0.141 & 5367 & Jamaica & 0.342 & 0.028 & - \\
\hline Australia & 0.181 & 0.066 & 9788 & Japan & 0.244 & 0.024 & 9583 \\
\hline Austria & 0.167 & - & 8174 & Jordan & 0.310 & 0.037 & - \\
\hline Barbados & 0.181 & 0.009 & 3835 & Malaysia & 0.038 & 0.013 & 888 \\
\hline Belgium & 0.204 & 0.032 & 8345 & Mexico & 0.325 & 0.008 & 2665 \\
\hline Bolivia & 0.165 & 0.023 & 945 & Morocco & 0.530 & 0.188 & 660 \\
\hline Brazil & 0.322 & 0.037 & 1540 & Netherlands & 0.176 & 0.080 & 9215 \\
\hline Bulgaria & 0.245 & - & - & New Zealand & 0.173 & 0.084 & - \\
\hline Canada & 0.187 & 0.043 & 10,195 & Nicaragua & 0.344 & - & 1074 \\
\hline Chile & 0.231 & 0.017 & 1924 & Norway & 0.238 & 0.078 & $11,760.550$ \\
\hline Colombia & 0.308 & - & 1243 & Pakistan & 0.819 & 0.002 & 207.590 \\
\hline Costa Rica & 0.209 & 0.067 & 1818 & Panama & 0.365 & 0.018 & 1965 \\
\hline Cuba & 0.431 & - & - & Peru & 0.421 & 0.019 & 1802 \\
\hline Dominica & 0.401 & 0.015 & - & Philippines & 0.363 & 0.005 & 726 \\
\hline Ecuador & 0.389 & 0.018 & 836 & Poland & 0.229 & - & - \\
\hline El Salvador & 0.260 & 0.023 & 1581 & Portugal & 0.199 & 0.065 & 2726 \\
\hline Fiji & 0.362 & 0.002 & 1123 & Puerto Rico & 0.164 & - & 4459 \\
\hline Finland & 0.219 & 0.031 & 8142 & Romania & 0.465 & - & - \\
\hline France & 0.294 & 0.041 & 8386 & South Africa & 0.149 & - & 2387.451 \\
\hline Germany & 0.152 & - & - & Spain & 0.221 & 0.121 & 4596 \\
\hline Ghana & 0.615 & - & 285 & Sri Lanka & 0.361 & 0.012 & 281.504 \\
\hline Greece & 0.351 & 0.032 & 4056 & Sweden & 0.177 & 0.049 & $12,764.210$ \\
\hline Grenada & 0.280 & 0.020 & - & Switzerland & 0.182 & 0.100 & - \\
\hline Guam & 0.038 & - & - & Thailand & 0.298 & 0.003 & 352 \\
\hline Guyana & 0.283 & 0.019 & 667 & Trinidad and Tobago & 0.222 & 0.019 & 3886 \\
\hline Haiti & 0.440 & 0.015 & - & Turkey & 0.295 & 0.012 & 1664 \\
\hline Honduras & 0.349 & 0.014 & 767 & UK & 0.094 & 0.020 & 10,600 \\
\hline Hungary & 0.129 & 0.002 & 1809 & Uruguay & 0.231 & 0.082 & 4140 \\
\hline
\end{tabular}

Source: Self-employment and employer shares: average 1949/50, 1955, 1964 (UN Demographic Yearbooks); Constant 2000 GDP per capita in USD: World Development Indicators, average 1960-1965 


\section{References}

Acs, Z., Desai, S., \& Klapper, L. (2008). What does "entrepreneurship" data really show? Small Business Economics, 31(3), 265-281. doi:10.1007/s11187-008-9137-7.

Acs, Z., Audretsch, D., Braunerhjelm, P., \& Carlsson, B. (2012). Growth and entrepreneurship. Small Business Economics, 39(2), 289-300. doi:10.1007/s11187-010-9307-2.

Acs, Z. J., \& Virgill, N. (2010). Entrepreneurship in developing countries. Foundations and Trends in Entrepreneurship, 6(1), 1-68. doi:10.1561/0300000031.

Akee, R. K. Q., Jaeger, D. A., \& Tatsiramos, K. (2013). The persistence of self-employment across borders: New evidence on legal immigrants to the united states. Economics Bulletin, 33(1), 126-137.

Aldrich, H. E., \& Waldinger, R. (1990). Ethnicity and entrepreneurship. Annual Review of Sociology, 16, 111-135. doi:10.1146/annurev.so.16.080190.000551.

Alesina, A., \& Giuliano, P. (2010). The power of the family. Journal of Economic Growth, 15(2), 93-125. doi:10.1007/ s10887-010-9052-z.

Alesina, A., \& Giuliano, P. (2011). Family ties and political participation. Journal of the European Economic Association, 9(5), 817-839. doi:10.1111/j.1542-4774.2011. 01024.x.

Alesina, A., Giuliano, P., \& Nunn, N. (2011). Fertility and the plough. American Economic Review, 101(3), 499-503. doi:10.1257/aer.101.3.499.

Ardagna, S., \& Lusardi, A. (2010). Explaining international differences in entrepreneurship: The role of individual characteristics and regulatory constraints. In J. Lerner \& A. Schoar (Eds.), International differences in entrepreneurship (pp. 17-62). Chicago: University of Chicago Press. doi:10.7208/chicago/9780226473109.003.0002.

Armington, C., \& Acs, Z. J. (2002). The determinants of regional variation in new firm formation. Regional Studies, 36(1), 33-45. doi:10.1080/00343400120099843.

Audretsch, D. B., Keilbach, M. C., \& Lehmann, E. E. (2006). Entrepreneurship and economic growth. New York: Oxford University Press Inc. doi:10.1111/j.1467-7660. 2008.00473_4.x.

Autio, E. (2007). Global entrepreneurship monitor: 2007 global report on high-growth entrepreneurship, Babson College and London Business School.

Bergmann, H., \& Sternberg, R. (2007). The changing face of entrepreneurship in germany. Small Business Economics, 28(2-3), 205-221. doi:10.1007/s11187-006-9016-z.

Bisin, A., \& Verdier, T. (2010). The economics of cultural transmission and socialization. NBER Working Papers 16512, National Bureau of Economic Research, Inc. doi: 10.3386/w16512.

Bjørnskov, C., \& Foss, N. (2008). Economic freedom and entrepreneurial activity: Some cross-country evidence. Public Choice, 134(3), 307-328. doi:10.1007/s11127-0079229-y.

Blanchflower, D. G. (2000). Self-employment in OECD countries. Labour Economics, 7(5), 471-505. doi:10.1016/ S0927-5371(00)00011-7.
Blanchflower, D. G., \& Oswald, A. J. (1998). What makes an entrepreneur? Journal of Labor Economics, 16(1), 26-60. doi:10.1086/209881.

Blanchflower, D. G., Oswald, A. J., \& Stutzer, A. (2001). Latent entrepreneurship across nations. European Economic Review, 45(4-6), 680-691. doi:10.1016/S00142921(01)00137-4.

Borjas, G. J. (1985). Assimilation, changes in cohort quality, and the earnings of immigrants. Journal of Labor Economics, 3(4), 463-489. doi:10.1086/298065.

Borjas, G. J. (1986). The self-employment experience of immigrants. The Journal of Human Resources, 21(4), 485-506. doi:10.2307/145764.

Bruhn, M. (2011). License to sell: The effect of business registration reform on entrepreneurial activity in Mexico. The Review of Economics and Statistics, 93(1), 382-386. doi:10.1162/REST_a_00059.

Carroll, C. D., Rhee, B. K., \& Rhee, C. (1994). Are there cultural effects on saving? some cross-sectional evidence. The Quarterly Journal of Economics, 109(3), 685-699. doi:10. 2307/2118418.

Clark, K., \& Drinkwater, S. (2000). Pushed out or pulled in? self-employment among ethnic minorities in England and wales. Labour Economics, 7(5), 603-628. doi:10.1016/ S0927-5371(00)00015-4.

Constant, A., \& Zimmermann, K. F. (2006). Legal status at entry, economic performance and self-employment proclivity: A bi-national study of immigrants. CEPR Discussion Papers 5696, C.E.P.R. Discussion Papers.

Djankov, S. (2009). The regulation of entry. World Bank Research Observer, 24(2), 183-203. doi:10.1093/wbro/ $1 \mathrm{kp} 005$.

Djankov, S., La Porta, R., Lopez-De-Silanes, F., \& Shleifer, A. (2002). The regulation of entry. Quarterly Journal of Economics, 117(1), 1-37. doi:10.1162/ 003355302753399436.

Djankov, S., Miguel, E., Qian, Y., Roland, G., \& Zhuravskaya, E. (2005). Who are Russia's entrepreneurs? Journal of the European Economic Association, 3(2-3), 587-597. doi:10. 1162/jeea.2005.3.2-3.587.

Djankov, S., Qian, Y., Roland, G., \& Zhuravskaya, E. (2006). Who are china's entrepreneurs? American Economic Review, 96(2), 348-352. doi:10.1257/ 000282806777212387.

Dreher, A., \& Gassebner, M. (2013). Greasing the wheels of entrepreneurship? the impact of regulations and corruption on firm entry. Public Choice, 155(3-4), 413-432. doi:10. 1007/s11127-011-9871-2.

Evans, D. S., \& Jovanovic, B. (1989). An estimated model of entrepreneurial choice under liquidity constraints. Journal of Political Economy, 97(4), 808-827. doi:10.1086/ 261629.

Evans, D. S., \& Leighton, L. S. (1989). Some empirical aspects of entrepreneurship. The American Economic Review, 79(3), 519-535.

Fairlie, R., \& Woodruff, C. M. (2010). Mexican-american entrepreneurship. The BE Journal of Economic Analysis \& Policy, 10(1), 1-44. doi:10.2139/ssrn.907681.

Fairlie, R. W., \& Meyer, B. D. (1996). Ethnic and racial selfemployment differences and possible explanations. The 
Journal of Human Resources, 31(4), 757-793. doi:10. 2307/146146.

Fairlie, R. W., Zissimopoulos, J., \& Krashinsky, H. (2010). The international asian business success story? a comparison of chinese, indian and other asian businesses in the united states, canada and united kingdom. In J. Lerner \& A. Schoar (Eds.), International differences in entrepreneurship (pp. 179-208). Chicago: University of Chicago Press. doi:10.7208/chicago/9780226473109.003.0007.

Fernández, R. (2008). Culture and economics. In S. N. Durlauf \& L. E. Blume (Eds.), The new Palgrave dictionary of economics. Basingstoke: Palgrave Macmillan. doi:10. 1057/9780230226203.0346.

Fernández, R., \& Fogli, A. (2006). Fertility: The role of culture and family experience. Journal of the European Economic Association, 4(2-3), 552-561. doi:10.1162/jeea.2006.4.23.552 .

Fernández, R., \& Fogli, A. (2009). Culture: An empirical investigation of beliefs, work, and fertility. American Economic Journal: Macroeconomics, 1(1), 146-177. doi:10.1257/mac.1.1.146.

Fernández-Serrano, J., \& Romero, I. (2014). About the interactive influence of culture and regulatory barriers on entrepreneurial activity. International Entrepreneurship and Management Journal, 10(4), 781-802. doi:10.1007/ s11365-014-0296-5.

Fitzsimmons, J. R., \& Douglas, E. J. (2011). Interaction between feasibility and desirability in the formation of entrepreneurial intentions. Journal of Business Venturing, 26(4), 431-440. doi:10.1016/j.jbusvent.2010.01.001.

Giuliano, P. (2007). Living arrangements in western Europe: Does cultural origin matter? Journal of the European Economic Association, 5(5), 927-952. doi:10.1162/JEEA. 2007.5.5.927.

Glaeser, E. L. (2007). Entrepreneurship and the city. NBER Working Papers 13551, National Bureau of Economic Research Inc.

Greif, A. (1989). Reputation and coalitions in medieval trade: Evidence on the Maghribi traders. Journal of Economic History, 49(4), 857-882. doi:10.1017/S0022050700009475.

Greif, A. (1993). Contract enforceability and economic institutions in early trade: The maghribi traders' coalition. American Economic Review, 83(3), 525-548.

Greif, A. (1994). Cultural beliefs and the organization of society: A historical and theoretical reflection on collectivist and individualist societies. Journal of Political Economy, 102(5), 912-950. doi:10.1086/261959.

Guiso, L., Sapienza, P., \& Zingales, L. (2003). People's opium? religion and economic attitudes. Journal of Monetary Economics, 50(1), 225-282. doi:10.1016/S03043932(02)00202-7.

Guiso, L., Sapienza, P., \& Zingales, L. (2004). The role of social capital in financial development. The American Economic Review, 94(3), 526-556. doi:10.1257/0002828041464498.

Guiso, L., Sapienza, P., \& Zingales, L. (2006). Does culture affect economic outcomes? Journal of Economic Perspectives, 20(2), 23-48. doi:10.1257/jep.20.2.23.

Hamilton, B. H. (2000). Does Entrepreneurship Pay? an empirical analysis of the returns to self-employment. Journal of Political Economy, 108(3), 604-631. doi:10. 1086/262131.
Hendricks, L. (2002). How important is human capital for development? evidence from immigrant earnings. American Economic Review, 92(1), 198-219. doi:10.1257/ 000282802760015676.

Henrekson, M., \& Sanandaji, T. (2014). Small business activity does not measure entrepreneurship. Proceedings of the National Academy of Sciences, 111(5), 1760-1765. doi:10. 1073/pnas.1307204111.

Hyytinen, A., Ilmakunnas, P., \& Toivanen, O. (2013). The return-to-entrepreneurship puzzle. Labour Economics, 20(C), 57-67.

Iyer, R., \& Schoar, A. (2010). Are there cultural determinants of entrepreneurship? In J. Lerner \& A. Schoar (Eds.), International differences in entrepreneurship (pp. 209-240). Chicago: University of Chicago Press. doi:10.7208/ chicago/9780226473109.003.0008.

Kaplan, D. S., Piedra, E., \& Seira, E. (2011). Entry regulation and business start-ups: Evidence from Mexico. Journal of Public Economics, 95(11), 1501-1515. doi:10.2139/ssrn. 978863.

Klapper, L., Laeven, L., \& Rajan, R. (2006). Entry regulation as a barrier to entrepreneurship. Journal of Financial Economics, 82(3), 591-629. doi:10.1016/j.jfineco.2005.09. 006.

Klapper, L., Amit, R., \& Guillén, M. (2010). Entrepreneurship and firm formation across countries. In J. Lerner \& A. Schoar (Eds.), International differences in entrepreneurship (pp. 129-158). Chicago: University of Chicago Press. doi:10.7208/chicago/9780226473109.003.0005.

Landes, D. S. (1999). The wealth and poverty of nations: Why some are so rich and some so poor. New York: W.W. Norton. doi: 10.2307/2658019.

Levie, J., Autio, E., Acs, Z., \& Hart, M. (2014). Global entrepreneurship and institutions: An introduction. Small Business Economics, 42(3), 437-444. doi:10.1007/s11187013-9516-6.

Liñán, F., \& Fernandez-Serrano, J. (2014). National culture, entrepreneurship and economic development: Different patterns across the European Union. Small Business Economics, 42(4), 685-701. doi:10.1007/s11187-013-9520-x.

Lofstrom, M. (2002). Labor market assimilation and the selfemployment decision of immigrant entrepreneurs. Journal of Population Economics, 15(1), 83-114. doi:10.1007/ PL00003841.

Michelacci, C., \& Silva, O. (2007). Why so many local entrepreneurs? The Review of Economics and Statistics, 89(4), 615-633. doi:10.1162/rest.89.4.615.

Mueller, P. (2006). Entrepreneurship in the region: Breeding ground for nascent entrepreneurs? Small Business Economics, 27(1), 41-58. doi:10.1007/s11187-006-6951-7.

Ohlsson, H., Broomé, P., \& Bevelander, P. (2012). Self-employment of immigrants and natives in Sweden a multilevel analysis. Entrepreneurship \& Regional Development: An International Journal, 24(5-6), 405-423. doi:10.1080/ 08985626.2011.598570.

Osili, U. O., \& Paulson, A. L. (2008). Institutions and financial development: Evidence from international migrants in the united states. The Review of Economics and Statistics, 90(3), 498-517. doi:10.1162/rest.90.3.498.

Oyelere, R. U., \& Belton, W. (2008). The role of information and institutions in understanding the black-white gap in 
self-employment. IZA Discussion Papers 3761, Institute for the Study of Labor (IZA), doi:10.1111/j.0042-7092. 2007.00700.x.

Oyelere, R. U., \& Belton, W. (2012). Coming to America: Does having a developed home country matter for self-employment in the united states? American Economic Review, 102(3), 538-542. doi:10.1257/aer.102.3.538.

Putnam, R. D., Leonardi, R., \& Nanetti, R. (1993). Making democracy work: Civic traditions in modern Italy. Princeton: Princeton University Press. doi:10.1002/ncr. 4100820215.

Rees, H., \& Shah, A. (1986). An empirical analysis of selfemployment in the UK. Journal of Applied Econometrics, 1(1), 95-108. doi:10.1002/jae.3950010107.

Reynolds, P., Storey, D. J., \& Westhead, P. (1994). Special issue: Regional variations in new firm formation. Regional Studies, 28(4), 343-456. doi:10.1080/ 00343409412331348386.

Reynolds, P. D., Hay, M., \& Camp, S. M. (1999). Gem 1999 global report. Tech. rep., Global Entrepreneurship Monitor.

Roland, G. (2004). Understanding institutional change: Fastmoving and slow-moving institutions. Studies in Comparative International Development (SCID), 38(4), 109-131. doi:10.1007/bf02686330.

Ruggles, S., Sobek, M., Alexander, T., Fitch, C. A., Goeken, R., Hall, P. K., King, M., \& Ronnander, C. (2008). Integrated public use microdata series: Version 4.0 [machine-readable database]. Minneapolis, MN: Minnesota Population Center [producer and distributor].

Stuetzer, M., Obschonka, M., Brixy, U., Sternberg, R., \& Cantner, U. (2014). Regional characteristics, opportunity perception and entrepreneurial activities. Small Business Economics, 42(2), 221-244. doi:10.1007/s11187-0139488-6.

Tabellini, G. (2010). Culture and institutions: Economic development in the regions of Europe. Journal of the European Economic Association, 8(4), 677-716. doi:10. 1111/j.1542-4774.2010.tb00537.x.

Tubergen, Fv. (2005). Self-employment of immigrants: A crossnational study of 17 western societies. Social Forces, 84(2), 709-732. doi:10.1353/sof.2006.0039.

van Hoorn, A., \& Maseland, R. (2010). Cultural differences between east and west germany after 1991: Communist values versus economic performance? Journal of Economic Behavior \& Organization, 76(3), 791-804. doi:10. 1016/j.jebo.2010.10.003.

Wyrwich, M. (2015). Entrepreneurship and the intergenerational transmission of values. Small Business Economics, 45(1), 191-213. doi:10.1007/s11187-015-9649-x.

Yuengert, A. M. (1995). Testing hypotheses of immigrant selfemployment. The Journal of Human Resources, 30(1), 194-204. doi:10.2307/146196. 